\title{
TOURISM, DEVELOPMENT AND PROTECTED AREAS: DECONSTRUCTING THE MYTH
}

Mª Luisa Gómez Moreno', Luis Miguel Rubio Barquero²

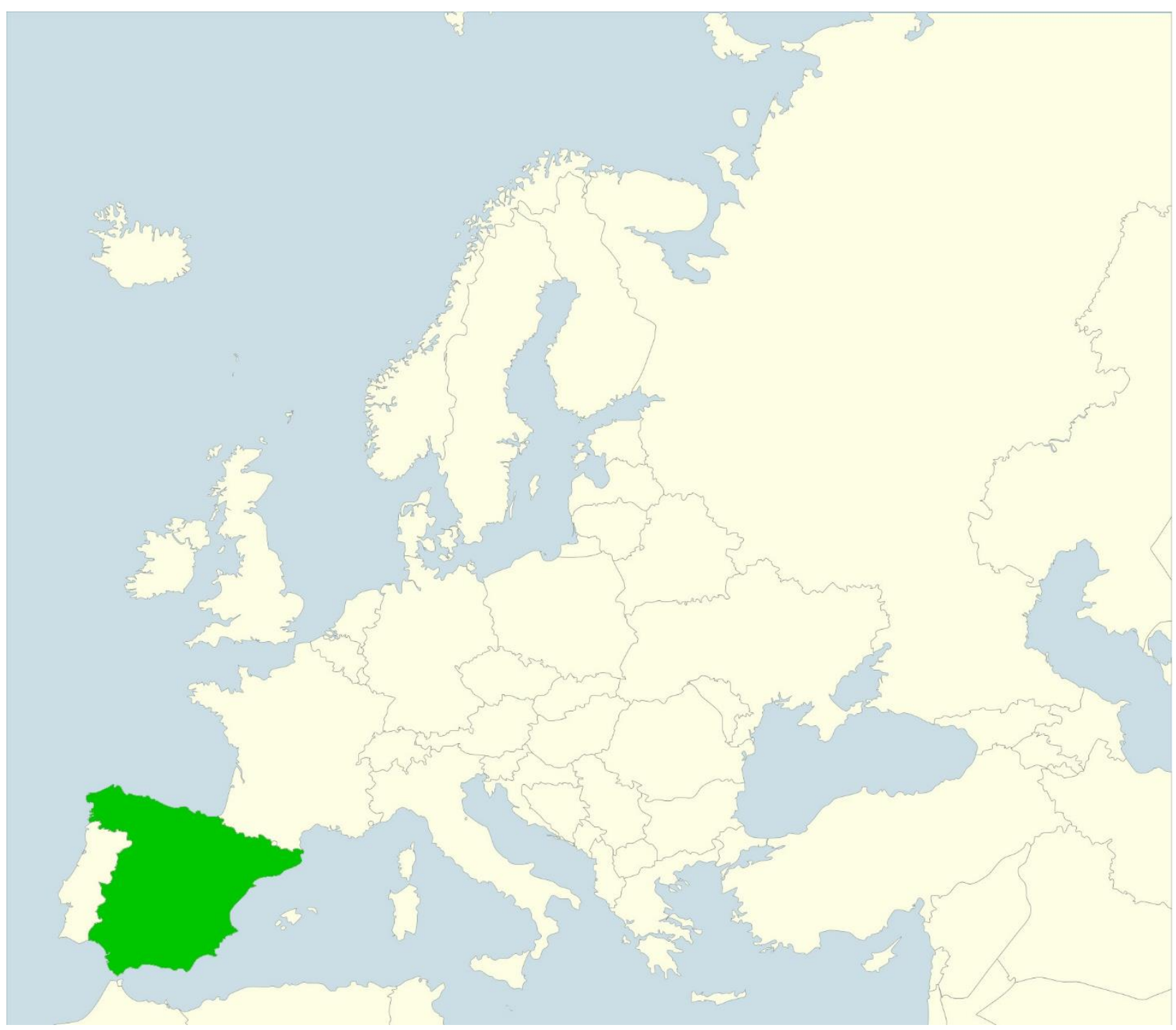

\footnotetext{
${ }^{1}$ Prof. María-Luisa Gómez-Moreno, Department of Geography, University of Málaga, Campus de Teatinos 29070 Málaga, Spain; email: geolugom@uma.es, ORCID: 0000-0002-4464-0187

${ }^{2}$ Luis Miguel Rubio Barquero, Doctoral candidate, University of Málaga, Campus de Teatinos 29070 Málaga, Spain; Imrubio@uma.es, ORCID: 0000-0003-4314-1244
} 
Abstract: The relation between tourism and rural development has been strengthened by planning frameworks such as rural development (the LEADER programmes) and by the management of protected natural areas. This relation also contributes to the concept of the multifunctionality of agricultural land. However, in the management of protected areas in Spain, the role of tourism and the public use of areas of maximum protection are often prioritised to the detriment of the agrarian societies with a permanent presence in these surroundings. In this paper, we analyse the impact of environmental planning and rural development on the characterisation of private tourist services in the Sierra de las Nieves natural park (near Málaga, Spain), using statistical sources, surveys and interviews with stakeholders. The results obtained show that the geographic distribution of private facilities is largely unrelated to public considerations. We view this outcome as a consequence of the disjunction between the agrarian traditions of local society and the new measures adopted to promote tourist activities.

Key words: Tourism and rural development; Outdoor recreation in protected natural areas; Mountain areas in crisis; Mediterranean mountain areas

Abstract: La relación entre turismo y desarrollo rural se ha potenciado por marcos de planificación como el desarrollo rural (programas LEADER) o la gestión de espacios naturales protegidos. También forma parte del concepto de multifuncionalidad de las explotaciones agrarias. Sin embargo, la función del turismo en la gestión de las áreas protegidas en España está orientada al uso público en las zonas de máxima protección en detrimento de las sociedades agrarias que habitan sus entornos. En este artículo se analiza el impacto de la planificación ambiental y del desarrollo rural en la caracterización de los servicios turísticos privados del parque natural Sierra de las Nieves (Málaga, España). Se usan fuentes estadísticas y entrevistas y encuestas a los actores. Los resultados revelan que el patrón de localización de estos servicios está más relacionado con factores externos a ambos planeamientos. Estos resultados se explican como consecuencia de la desconexión entre las medidas que fomentan las actividades turísticas y las bases agrarias de la sociedad.

Keywords: turismo y desarrollo rural; actividades recreativas en áreas naturales protegidas; áreas de montaña en crisis; montaña mediterránea

\section{Introduction}

The economic repercussions of the creation of protected areas (PAs) has an impact on our understanding of the European rural landscape in several ways. Firstly, because of the large area they occupy, almost 1.2 million km² (European Environmental Agency, 2012). Secondly, because PAs are mainly located in mountain areas, which are often economically depressed, as is the case of those in the Mediterranean area (López et al., 2007). Thirdly, and related to the previous two, is the fact that PAs are associated with policies that are not always compatible, even within the context of sustainable development, for example, those aimed at protecting biodiversity and those focused on rural development.

However, as observed by Mayer and Job (2014), the importance of these questions is not reflected in a corresponding degree of attention by academic studies in Europe. This is especially true with respect to Spain, where the proliferation of PAs since the adoption of Act 4/1989, of 27 March, on the Conservation of Natural Areas and Wild Life has led to many studies being conducted on the theoretical conversion of these areas into tourist destinations, whilst little attention has been paid to whether this theory has been put into practice. This disjunction is also apparent in the focus on rural development programmes (LEADER), which have been applied almost in parallel to the expansion of PAs. 
Taking into account the above considerations, the present study has the following main aims:

1. To analyse the process and results of the connection between tourism, PAs, rural development policies and rural social structures, and thus determine the economic repercussions produced.

2. To identify the problems that may impede the effective management of PAs and rural development programmes, and to propose mechanisms for their solution.

These aims are addressed as follows:

1.-The study area chosen was that of the natural park (NP) of Sierra de las Nieves (Andalusia, Spain, Figure 1; Level V IUCN), which is also subject to other measures of protection, forming part of the UNESCO Biosphere Reserve and the EU Natura 2000 Network of Protected Areas. This area was chosen for study because it is a representative example of a Mediterranean mountain area in an EU country; many NPs are located in such areas. Furthermore, this NP has relatively low visitor numbers $(10,000-50,000)$, which is typical of Spain as a whole (EUROPARCESPAÑA, 2013) and of the region of Andalusia (Fernández \& Santos, 2010) in particular.

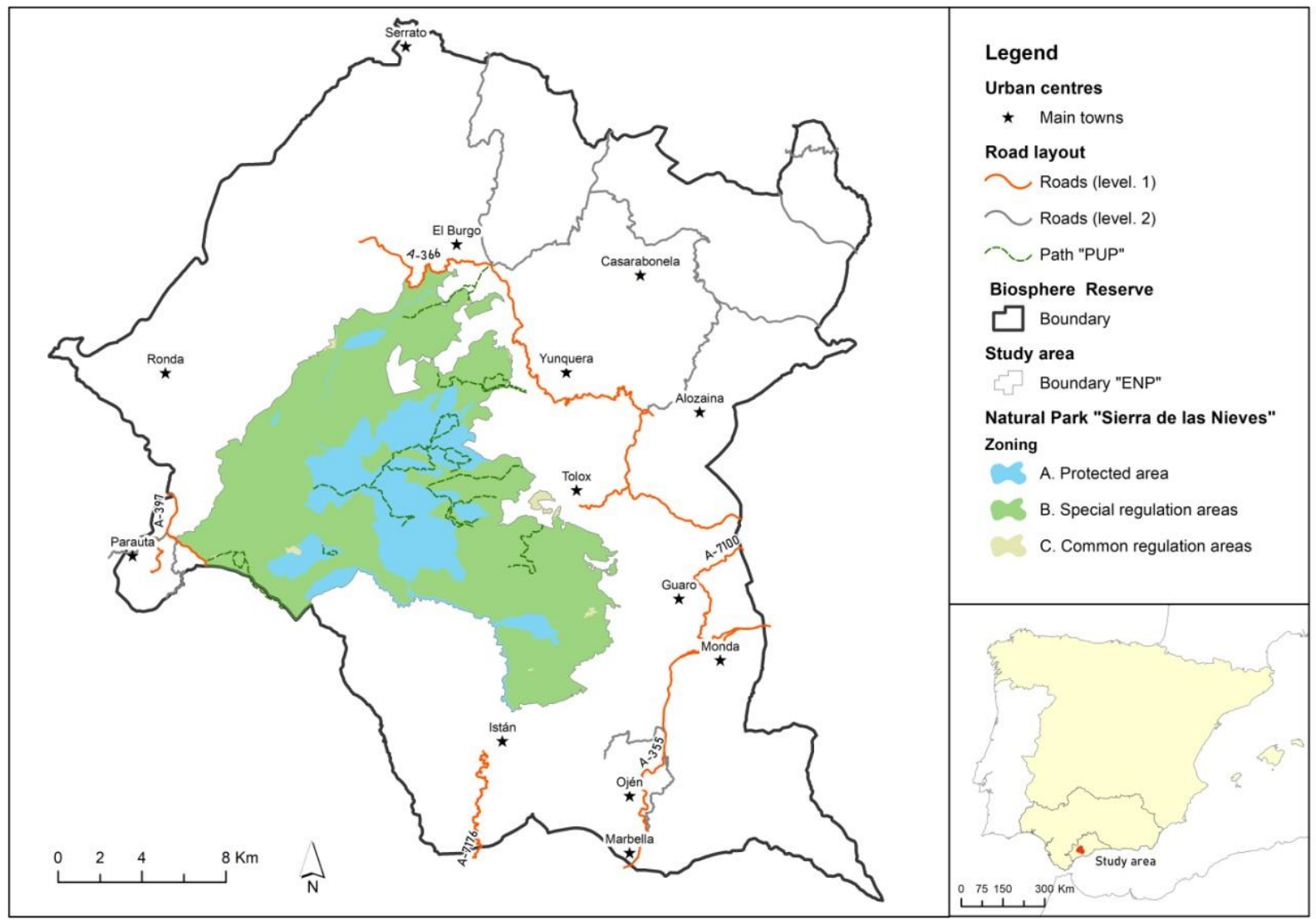

Fig 1. Study area. Outdoor recreation and zoning planning of Sierra de las Nieves NP. Source: REDIAM: https://descargasrediam.cica.es/repo/s/RUR

DERA:> https://www.juntadeandalucia.es/institutodeestadisticaycartografia/DERA/datos_espaciales.htm, retrieved November 2020

2.-The theoretical background assumed allows us to locate this problem within the framework of the EU and Spain. Moreover, the initial postulates taken are those of local development, in order to detect the problems described above. 
3.-Various sources and procedures were used $^{3}$, including an analysis of the environmental and rural development policies applied; statistical sources, to determine the degree of transformation of the local production system between 1991 and 2011; interviews with stakeholders, who informed us of their views on the tourism activities implemented; and surveys of users of the NP Public Use Programme (PUP). The results obtained are presented in statistical and cartographic form, with qualitative analyses.

\section{The study area as a selection factor for the epistemological framework. A Territory project}

The study area reflects the processes described in the Introduction. According to the European Environmental Agency (2012, p. 13), the area of the PAs in the European Union increased significantly between 1979 and 1989, and the first LEADER Community Initiative was implemented from 1991 to 1993 (Moyano et al., 2017, p. 92). The enlargement of PAs, this new, powerful category in land use planning, has produced an overlap with mountain areas where the unsuitability for industrial agriculture practices has preserved environmental values and biodiversity to a greater extent than elsewhere. However, application of this planning measure has not been uniform within PAs in the European Union, which recently introduced its own regulations in this respect, in the form of the Natura 2000 Network. In terms of the IUCN ranking (Dudley, 2008) and following Mayer \& Job (2014), the two most significant categories in this regarding visitor appeal are national parks (IUCN Category II), which normally attract most visitors, and regional nature-parks (IUCN Category V), which these authors identify with the UNESCO biosphere reserves (BRs); these attract fewer visitors and are subject to less stringent spatial zoning. Both types are present in the mid-mountain areas of the Spanish Mediterranean region of Andalusia. The national parks are administered in conjunction with the central government, while the natural parks, or regional nature-parks (NPs) are the sole responsibility of the regional government.

Figure 1 shows overlapping PAs in the study area: the Sierra de las Nieves NP and the Sierra de las Nieves BR (1995), both of which form part of the Natura 2000 Network (2015).

The area's declaration as a NP in 1989 was closely linked to the concept of biodiversity, since a major consideration in this decision was the unique presence of the Spanish fir (Abies pinsapo bois), whose location depends on the same factors, altitude and shade (providing humidity and cooler temperatures), that have enabled its survival as a relict species. This PA is located in the area known as Sierra del Pinar-de las Nieves, in the heart of the tectonically and lithologically complex mountains and foothills of the Serranía de Ronda (Senciales et al. 2017), which among other aspects constitute the boundary between different administrative zones. For this reason, the study area (Figure 1) lacked functional and administrative unity until its declaration as a NP in 1989. The relationship between this protection status and the municipal structure was first regulated by Act 4/1989 of 27 March on the Conservation of Natural Areas and Wild Life, and these principles were subsequently developed by Act 42/2007 of 13 December on Natural Heritage and Biodiversity. This legislation distinguished between NP, the area subject to specific regulations and management, and 'Area of Socioeconomic Influence' (ASI), defined as the sum of the municipal areas comprising the NP. Table 1 shows the municipalities corresponding to the area's declaration as a BR; some of these do not contribute surface area to the NP.

Despite its short history, the territorial restructuring resulting from the NP and BR declarations has led the municipalities involved to take part in successive editions of the LEADER prog ramme. Thus, in the first call for participation (1991-1994), the towns of El Burgo and Yunquera were incorporated into the Rural Development Centre (CEDER) of Ronda, which also included the municipality of Parauta. However, in the second LEADER programme (1995-99), El Burgo

\footnotetext{
${ }^{3}$ This paper is an outcome of the project Methodological Development on Assessing the Capacity of Protected Areas for Recreational Uses (Desarrollo metodológico sobre la evaluación de la capacidad para usos recreativos de espacios protegidos), reference SEJ2007, as part of the 2004-2007 National Plan for Scientific Research, Development and Technological Innovation, and the 2007 research excellence programme supported by the Regional Government of Andalusia
} 
and Yunquera left this association to join the DESSNIEN Local Action Group ${ }^{4}$ created specifically to participate in the second LEADER programme, which included most of the municipalities located within the NP and the BR. Hence, the municipalities of the NP have taken part in different programmes of rural development. Similarly, the Sierra de las Nieves Association of Municipalities (Table 1), which was created by these bodies to coordinate functions and policies, is a significant reflection of the presence and importance of these municipalities. The exclusion of Parauta from this Association has led it to be marginalised from the overall dynamics of the BR, but this exclusion is mainly due to the village's isolation by road from the eastern edge of the BR (see Figure 1).

In parallel to this institutional structure, there is a socioeconomic one, in which proximal municipalities may present widely varying socioeconomic conditions ${ }^{5}$. The southern edge of the NP overlooks the Western Costa del Sol (the municipalities of Istán, Ojén, Guaro and Monda), an extensive, tourism-oriented urban area; the eastern slope (with the municipalities of Alozaina, Casarabonela, Tolox and Yunquera) is functionally associated with the city of Malaga via the Guadalhorce valley; the northern and western slopes are the least populated, containing only the villages of El Burgo and Parauta, respectively. As can be seen in Table 1, the town of Ronda, with almost 35,000 inhabitants, breaks the relative homogeneity of the population distribution; most of the other municipalities have around 2,000 inhabitants. Its presence reflects the historic growth of medium-sized towns located in areas that are favourably situated with respect to nearby mountains, with good pastures for livestock and ready access for forestry exploitation. Furthermore, the surface area of this municipality contains a significant proportion of all the Spanish firs in the NP. Ronda is world famous for its historic, architectural and landscape heritage and did not suffer the population decline experienced by the other municipalities in the area (Figure 2) following the significant upturn in the Spanish economy from 1958, which triggered an intense exodus from the country, especially from these mountain areas. For this reason, Ronda is excluded from the scope of the present study.

Tab 1.Municipalities located within the NP and the BR.

\begin{tabular}{|l|l|l|c|c|c|c|}
\hline $\begin{array}{c}\text { Natural } \\
\text { Park }\end{array}$ & $\begin{array}{c}\text { Biosphere } \\
\text { Reserve }\end{array}$ & $\begin{array}{c}\text { Association of } \\
\text { Municipalities }\end{array}$ & $\begin{array}{c}\text { NP } \\
\text { surface } \\
\text { area } \\
\text { (ha) }\end{array}$ & $\begin{array}{c}\text { Mpy. surface } \\
\text { area } \\
\text { (ha) }\end{array}$ & $\begin{array}{c}\text { Surface area } \\
\text { protected (\% } \\
\text { of NP) }\end{array}$ & $\begin{array}{c}\text { Population } \\
(2016)\end{array}$ \\
\hline & Alozaina & Alozaina & & 3,390 & & 2,030 \\
\hline Burgo (El) & Burgo (El) & Burgo (El) & 1,407 & 11,660 & 12.07 & 1,871 \\
\hline & Casarabonela & Casarabonela & & 11,320 & & 2,573 \\
\hline & Guaro & Guaro & & 2,240 & & 2,047 \\
\hline Istán & Istán & Istán & 1,160 & 9,933 & 11.58 & 1,399 \\
\hline Monda & Monda & Monda & 978 & 5,766 & 16.95 & 2,400 \\
\hline & Ojén & Ojén & & 8,560 & & 3,385 \\
\hline Parauta & Parauta & Parauta & 2,806 & 4,449 & 63.63 & 230 \\
\hline Ronda & Ronda & & 4,757 & 48,131 & 9.79 & 34,381 \\
\hline Tolox & Tolox & Tolox & 6,771 & 9,444 & 72.19 & 2,093 \\
\hline Yunquera & Yunquera & Yunquera & 2,120 & 5,515 & 36.74 & 2,948 \\
\hline Total & Total & & 19,999 & 120,408 & 20.92 & \\
\hline
\end{tabular}

Sources: Population, 2016 Census, Spanish Institute of Statistics (INE); Surface area of municipalities, 1:25,000 maps of the National Geographic Institute; Surface area of protected areas:

http://www.juntadeandalucia.es/medioambiente/web/Bloques_Tematicos/Patrimonio_Natural._Uso_Y_Gestion/Espac ios_Protegidos/PDS/PDS_Sierra_de_las_Nieves/parte1.pdf. October 2010.; Association of municipalities, https://www.sierradelasnieves.es/municipios-2/

\footnotetext{
${ }^{4}$ Asociación Grupo de Desarrollo Rural Sierra de las Nieves, AGDR (Association for the Rural Development of Sierra de las Nieves).

${ }^{5}$ The sociodemographic characteristics of the study área, at the regional scale, are described in Senciales et al. (2017).
} 


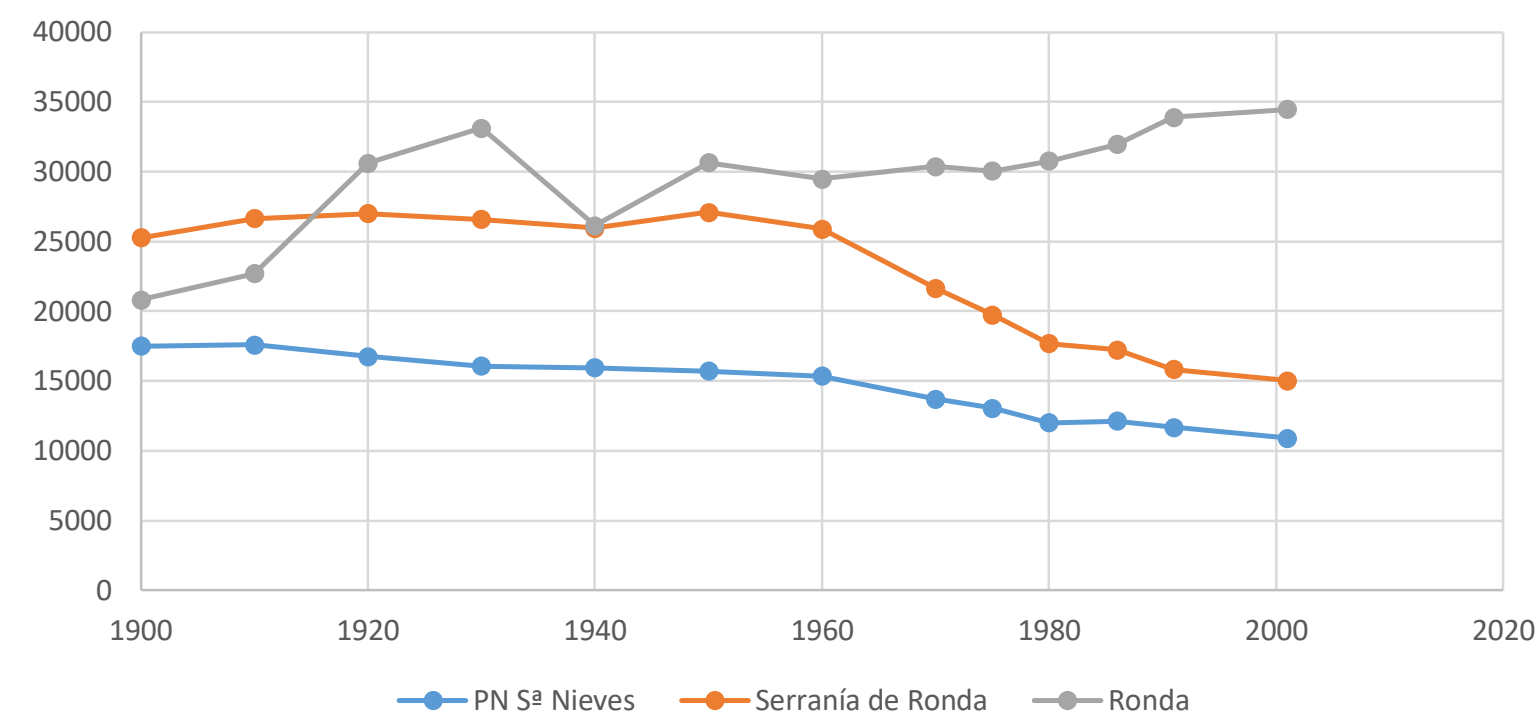

Fig 2. Population in the study area 1900-2019. Source: INE, Population censuses 1900-2011

In summary, over the last 20 years the study area has undergone a process of territorial construction, in a project consisting of two policies, rural and environmental, conducted in parallel. The question arises: have these policies been implemented in a sufficiently coordinated and effective way to reverse the area's long-term economic and demographic decline? Our bibliographic review addresses this question.

\section{Conceptual framework: promoting tourism in PAs to revitalise rural areas in decline}

The research question we consider has been addressed previously, using different theoretical frameworks, but the evaluations made do not always coincide. One of the first studies of the transformation of alpine mountain areas into destinations for tourism, as a spontaneous process and unrelated to the protection of the natural world, was performed by Groupe Grenoble (1979), which rightly diagnosed this process as space délaisse, space convoité[virgin space, desired space]. At an even earlier date, Henry Troyat in his novel La neige en deuil (1952) had grasped the fact that this transformation highlights the weakness of social structures in mountain areas, in that young people in alpine communities are attracted by the recreational and aesthetic appeal of urban visitors. In other words, tourism does not revitalise the rural environment on which it rests, but consumes it.

In the European Union, the large-scale extension of PAs took place at a later date, which explains why the first academic investigation of their socioeconomic effects took place in the AngloAmerican context, focusing on the outdoor recreation use of these areas (Wagar, 1964). In European studies conducted in the 1980s and 1990s, the role of tourism as a mechanism for revitalising rural areas was considered in terms of two paradigms.

The first was focused on the impact of tourism, which was considered both by planners and by academics to be an instrument that energised rural environments in general, and those with protected status in particular. In this respect, the World Tourism Organisation (WTO) stated in 1993,"If a community has the right type of resources, it may be the opportunity to develop tourism which can bring substantial benefits to the community and its residents. To succeed, tourism in the community must be planned and managed to improve the quality of life of residents and to protect the local, natural and cultural environment. Protecting the environment and achieving successful tourism development are inseparable" (apud Spotorno, 2005, p. 49). Twenty years later, Mayer and Job (2014, p. 83) made this observation: "In general, the economic impact analyses of PA tourism prove that PA play a very important role in nature-based tourism in the mostly peripheral rural PA regions in the German-speaking countries, where they are often 
part of implicit or explicit regional development strategies which aim at reducing disparities by stimulating tourism". These outlooks are, in fact, convergent. According to the WTO definition, appropriate planning of tourist activity, in itself, is sufficient to make conservation compatible with the quality of life of the local population, assuming that the latter's social structures are capable of accommodating the impact of tourism within the pre-existing socioeconomic fabric. This syllogism is fulfilled forPAs, which are identified as destinations that are especially suitable for nature tourism, where the economic activities thus promoted are viewed by local populations as legitimate compensation for the restrictions imposed by environmental protection regulations. Research studies conducted in Spain generally concur with this positive assessment of the impact of tourism on PAs (Antón et al., 2008; Fernández \& Santos, 2010; Prados, 2008; Pulido, 2008; Reinoso \& Sáncho, 2011; Serrano \& Aparicio, 2017; Tolón \& García, 2002).

In the technical context and in the same time frame, the LEADER programme and related measures in general, and those employed in Spain in particular, focus on rural tourism as the main instrument involved, thus implicitly accepting the WTO assumptions.

However, contrary to this optimism, other studies have warned of the real problems that may be faced by a community if, having experienced a sharp decline in its socioeconomic life, after decades of agricultural activities, it wagers its future on tourism. Thus, Van der Straaten (2000, p. 221) highlighted a significant drawback to this policy shift: "The crucial question is to what extent communities in these areas are able to organise economic life in such a way that sustainable tourism can be facilitated and promoted to the benefit of the local stakeholders". A similar critical line has been expressed, among others, by Bachiller, 2012; Benos et al., 2007; Capdepón, 2015; Ciervo, 2013; Cortijo \& Pulido, 2016; Etxano, 2009; García, 2011; Horakova, 2013; Leco et al., 2015; Martínez \& Romero, 2003; Mulero, 2005 and Troitiño, 1995.

The second paradigm was also developed in the 1990s, in studies of the rural context. This was the concept of the multifunctionality of agricultural exploitation (Souchon Report apud Prost, 1994), which repositioned the role of agriculture within a post-industrial society, and considered tourist activity to be one that the rural environment could and should accept. Other studies expanded this view. Thus, Pecqueur (2001) discussed the "basket of goods" model and Esparcia and Buciega (2005, p. 36) proposed the following concept of rural goods and services (RGS): ".. resources that are highly valued, like the countryside, natural resources, peace and quiet, tradition, authenticity, etc. that are materialised in RGS such as country houses, gastronomy, rural accommodation, local products, recreational activities based on natural resources (water, mountain, landscape), healthy products, etc.".

In our view, the above-mentioned limitations could be resolved via the paradigm of multifunctionality. But this would have to be done by incorporating another epistemological perspective, the sociological one, to analyse the relationship between culture and development. In this respect, Bericat $(1989$, p. 18), based on development theory, according to which culture is a fundamental factor, existing prior to development, stated "The importance of culture does not reside in the ease with which it can be modified, but in the fact that culture is the first area of transformation that can be, albeit partially, self-generating". Thus, if our goal is to make tourism a mechanism for the revitalisation of rural areas in decline, the first step should be to incorporate the new activities into "the cultural and social fabric of communities" (Ibidem p. 22), seeking, as an initial goal, to strengthen the management capacity of rural society. Although the conceptual framework of the LEADER programmes also includes the 'bottom-up' notion and the participation of local agents (Regourd, 2006), they have not been put into practice (Calvo, 2011; Cañete et al., 2017; Moyano et al., 2017), as administrators have focused instead on managing and implementing tourism-related projects, assuming that the social structures present would automatically suffice to insert these new ventures into the pre-existing socioeconomic system.

In short, tourism-related activities could be integrated into the rural structure, thereby favouring the synergy implicit in the concept of the multifunctionality of agricultural exploitation; on the other hand, such activities might become merely a burdensome appendage, in which the absence of any such synergy would greatly limit its ability to stimulate rural areas in decline. 


\section{Hypotheses}

From the above considerations, we propose the following hypotheses. In land planning, when consideration is given to declaring a PA and to implementing rural development initiatives, tourism is often assumed to be the main instrument for diversifying and strengthening upland environments, in the view that such initiatives will automatically convert the area in question into an attractive destination for tourist activities. However, the real evolution of the productive fabric in mid-mountain areas does not always reflect these expectations. We suggest this limitation arises from the following:

H1.1: The real capacity to diversify productive structure depends on: a) the volume and profile of the visitors attracted thereby; $b$ ) the attitudes and actions taken by social agents to transform or start up private companies on the basis of these public initiatives.

H1.2: The economic effects are not spread evenly over the entire area addressed by the declaration, and so some municipalities benefit (or are prejudiced) more than others.

\section{Materials, definitions and methods}

These hypotheses were tested by reference to the following sources and procedures.

\subsection{Sources and procedures common to all hypotheses}

The time frame considered is a medium-term one, ranging from the years immediately following the area's declaration as a NP (1989) up to the 2016 data for demand and supply. An aspect that is very relevant to our study hypotheses, according to Mayer and Job, is that of the scale considered to address the economic effects of PA status. In the present study, we analyse the effects produced on the NP, on the BR as a whole and on each of the municipalities within these areas, doing so by reference to the concepts, methods and sources set out below (see Tables 2 and 3).

The link between outdoor recreation in general, and hiking in particular, and the productive fabric has been established in a broader study aimed at developing a method to evaluate the capacity of PAs for recreational uses, conducted during the period 2007-13 (see Note 3). Henceforth, the latter research is cited as (Ocaña et al., 2012). To address the study aims, it was essential to characterise the users of the NP and to determine the perceptions of these users among local agents. Surveys are commonly used for this purpose in academic and applied research, both to obtain user profiles (Benito et al., 2011; García \& Barrena, 2013; Leco et al., 2015 ; Serrano, 2008; PRAMES, 2003) and to investigate the perceptions of local agents (Calvo, 2011; Capdepón, 2015; Cortijo, 2016; Horakova, 2013; Marsat et al., 2013; Pulido, 2008; Regourd, 2006; Rizzo, 2013). In the present case, three surveys were conducted, one that was common to the project as a whole (the PUP Users Survey ${ }^{6}$ ) and two that were specific to this research. The first was addressed to stakeholders (ISSI: Institutions, Stakeholders, Semi-structured Interview) while the second consisted of a questionnaire sent to the active tourism companies operating in the study area (ATES: Active Tourism Enterprise Survey). Table 3 details the main characteristics of these two instruments. As the results obtained were also applicable to other study hypotheses, our paper: a) describes the ISSI procedure in detail (in section 5.1.a); and b) states in each of the corresponding sections the use of these instruments as a data source.

a. ISSI: Institutions, Stakeholders, Semi-structured Interview

Planning in this respect (Table 3 ) is based on the prior identification of two social groups that are relevant to the aims of this study: a) Institutional agents, local or otherwise, responsible for different planning instruments related to rural development and recreational activities; b) Businesses, local or otherwise, in the sectors involved in the relationship between recreational activities and the rural productive fabric. The design of these interviews is based on a qualitative

\footnotetext{
${ }^{6}$ The planning and partial results of the PUP Users Survey have been presented elsewhere (see, among others, LuqueGil et al., 2018). Given its secondary role in our research, its method is not reproduced in detail here.
} 
exploitation of the data obtained, maximising the potential of semi-structured interviews, using ATLAS.ti software (which after importing the interview transcript permits the use of different coding options) and taking into account the existence of open-ended questions in the surveys. Consequently, these results are not presented in a single format; instead, specific points are referred to in the text, and contingency tables are used in which the presence or otherwise of public facilities in the municipality is a segregation factor.

\subsection{Identification of tourist activity-related measures in NP planning and rural development}

The basis for our analysisis the understanding that the planning and development policies applied influence both the location of tourist facilities and also their supply and demand. The analysis was conducted by reference to the following data sources:

- NP planning, published by Junta de Andalucía (2003).

- The LEADER + and PRODER A rural development programmes, published in AGDR 20002006, as part of the annual reports sent by the AGDR to the Regional Ministry of Agriculture (Junta de Andalucía). These reports include the projects approved annually.

- The actions taken by public institutions in this respect are documented from two complementary sources: on the one hand, the targeted use of internet search engines (Serrano, 2008) and on the other, interviews with local and regional institutions via the ISSI (see 5.1.a).

The procedures applied to these sources are based on identifying the initiatives and activities aimed at promoting the conversion of the study area into a tourist destination and/or revitalising its social structures.

- Among these initiatives, some are public activities aimed at promoting the study area.

- Others concern public facilities for outdoor recreation, addressed both in NP planning and in rural development policies. Although the theoretical discussion of a concept such as outdoor recreation, the definition of which has been much debated in recent years (Clemens et al., 2018), lies beyond the scope of our discussion, certain notions must be taken into account. As regards our study findings and their subsequent transfer to operational variables, certain fundamental aspects should be considered. The first is that of the relationship between the natural and the rural environments, which is implicit in the "outdoor" concept. In contrast to the identification that has been made between "outdoor" and the natural environment, expressed thus, "Recreational activities that happen within and rest on the natural settings is often used as the basic definition of outdoor recreation" (Clemens et al., 2008, 58), are the considerations of the LEADER European Observatory (2001) regarding one of the most widespread activities within outdoor recreation, namely hiking and trail walking. According to this Observatory, for most people, hiking is a recreational activity, not a sport, and is undertaken for many reasons, including an interest in the natural world. This definition implies a continuity between natural environments, whether protected or not, and those adapted for human use, to the extent that, for the visitor, a trail network is an instrument enabling movement and the enjoyment of the biodiversity and cultural values juxtaposed within the territory. Therefore, for the purposes of our study, the outdoor recreation activities considered are not restricted to those performed in "natural settings". The second essential aspect of our study is the analysis made of the activities and facilities that are an essential part of outdoor recreation, from the perspective of their impact on the local productive fabric, that is, depending on the type of investment and maintenance required and their relationship with the location (within or outside the study area). This analysis shows that activities such as mountain biking and off-road routes for quads and $4 \times 4$ vehicles (but not horse riding) are characterised by the mobility of the equipment required (i.e. it can readily be transferred from one site to another), thus enabling a separation between the location of the company involved and its employees, and the place where the activity is conducted. For hikers, the trail network, its signposting and maintenance are provided by the public authorities, without charge, and the use of guides is not essential for this practice. Therefore, a priori, relocation is not possible, and the cost of this activity ismet more from public than from private spending.

- A third group of activities consists of the projects approved and financed in the LEADER + (2001-2006) and PRODER A (2000-2006) programmes, for the purposes of creating private 
tourist facilities and/or revitalising social structures. In addressing this category, we took a twotier approach, in accordance with our study aims. The first approach is that of the interaction with rural social structures that is implicit in activity programming and execution. According to Bericat (1989), we should seek to determine an empirical relation, for specific communities, between cultural features, the ways in which wealth is assimilated and the types of socialisation or social interaction observed. In consequence, for a social context such as that of the study area, lacking practices of active participation in public processes, except that of voting at election times (and even that only relatively recently), an analysis of policies aimed at matching the cultural patterns of the population to the new economic possibilities offered via the LEADER + programme, thus overcoming collective limitations, should have been given the highest priority. Theoretically, this priority fully matches the bottom-up assumption inherent in both LEADER + and PRODER. Therefore, to identify this dimension, albeit approximately, we focused on the lines of action stipulated in these two programmes. The second approach we took was to identify the weight assigned to each line of action within projects designed to support private tourism activities. This process is complicated by the open, transversal formulation of the lines of action and so the presumed funding of the above projects was determined according to the corresponding National Classification of Economic Activities (CNAE, Spanish initials) code, formed by a branch letter and two digits. Due to limitations of space, a detailed economic analysis is not provided.

Having identified these initiatives, the following procedures were applied to summarise the data obtained (see Table 2):

- The planning documents were analysed and presented in accordance with the epistemological framework of conventional instrumental rationality (Simón et al., 2014), by means of in-text citations.

- The mapping of public facilities for outdoor recreation provided for in the planning and management of the NP was incorporated as an analysis factor for other variables (Fig. 1; Table 1, 5, 6, 11, 12; Figs. 3-8).

- The data were then categorised by the qualitative tabulation of public initiatives related to tourist activity (promoting either the study area in itself or organising activities related to outdoor recreation, Table 4).

- Quantitative tabulation was performed for the project financing approved annually in the LEADER + and PRODER programmes (AGDR 2000-2006) (see Table 7).

- Quantitative tabulation was performed for the funding obtained(total investment, in euros) for different lines of action in the LEADER+ and PRODER programmes (AGDR 2000-2006) (see Table 10).

\subsection{Measuring the effectiveness of these policies}

\section{a. Visitor numbers attracted}

- The number and temporal distribution of users of the NP trail network are determined by means of trail traffic counters (see note 3; for details of their characteristics, see Luque-Gil et al., 2018). In our paper, these data are used only in the in-text references.

- The number and timing of overnight stays analysed are based on data obtained by the Rural Tourism Accommodation Occupancy Survey, for the period 2005-2016 with an interruption of three years (2009-2011) and a month-by-month breakdown. Analysis of these data characterises one of the factors determining the economic profitability of private lodging. Unfortunately, as these data are presented only with respect to the entire area of ASI of the NP (not detailed by municipalities), the survey does not provide information on the spatial distribution of tourist activity. Furthermore, municipalities in the BR are not included. In our paper, these data are used only in the in-text references.

\section{b. Visitor profiles}

As indicated above, there are no statistical sources for visitor numbers for the whole study area (BR). However, the PUP Users, ISSI and ATES surveys do enable us to approximate the profile 
of three types of visitors: 1 . The users of NP facilities; 2 . The clients of accommodation, catering and other businesses located in the BR; 3 . The clients of active tourism companies.

To do so, the following items were considered, in each of the three surveys: 1 . Visitors' sociological characteristics (origin, social status, age, sex and group size (Table 5) and type of transport used; 2 . The frequency and seasonality of the use of public and private recreational facilities (Table 6); 3 . The recreational activities actually performed vs. those proposed in the PA management plan, by other institutions and by active tourism companies; 4 . Users' expenditure on private recreational facilities and stakeholders' estimates of the economic impact of hiking on the study area and on their establishments (Tables 11, 12).

In our qualitative analysis, responses were grouped according to the firm's location (in municipalities with or without a PUP), to determine the relation between the location of public outdoor recreation facilities specified in the PUP for the NP and the profile of users of private accommodation.

\section{c. Evolution and location of the supply of private-sector tourist services}

The impact produced on the supply of tourism-related goods is the most immediate manifestation of how tourism can affect the diversification and revitalisation of the productive fabric. To determine this question, the following sources, variables and procedures were used:

- The evolution of employment rates and of numbers of establishments (the procedure most commonly described in the bibliography consulted: Baños \& Rico, 2016; Capdepón, 2015; Fernández \& Santos, 2010; García, 2011; Jiménez et al., 2015; Pillet, 2011 ; Sánchez et al., 2017; Serrano, 2008). The following statistical sources (presented cartographically and by municipalities) were used: a) The population censuses for 1991, 2001 and 2011 (National Institute of Statistics), detailing the numbers of persons employed in hotels and catering (Fig. 3); b) The data on tourist establishments compiled by the Regional Ministry of Tourism, Commerce and Sport, for the period 1988-2016 (number of hotels, Fig. 4; number of campsites, Fig. 5; number of rural houses, Fig. 6; numberof apartments, Fig. 8; and number of restaurants). In our paper, the study data are presented in cartographic form, thus providing a visual representation of the relationship between the location of public outdoor recreation facilities (as described in the corresponding PUP) and that of the private accommodation available to tourists.

- The outdoor recreation facilities offered by active tourism companies operating in the study area, whether or not physically located there. These data (Table 9) were obtained from the ATES survey (see Table 3) and those for the recreational activities practised by clients of tourist establishments (Table 8), from the ISSI (see Table 3).

\section{d. The economic impact of public-sector initiatives, according to users and stakeholders}

Three types of information were considered in this analysis: a) stakeholders'assessments of the suitability of public-sector initiatives (ISSI); b) spending by users of the PUP on private tourism services (PUP User Survey); c) stakeholders' assessments of the economic effects of publicsector initiatives, according to clients' spending patterns and sociodemographic profiles (Tables 11 and 12). 
Tab 2. Subject, source, study period, scale and presentation of results.

\begin{tabular}{|c|c|c|c|}
\hline \multicolumn{4}{|c|}{ Subject: public and private offer of outdoor recreational facilities } \\
\hline \multicolumn{2}{|l|}{ Source and study period } & Subject & $\begin{array}{l}\text { Scale and } \\
\text { presentation of } \\
\text { results }\end{array}$ \\
\hline \multicolumn{2}{|l|}{ Junta de Andalucía, 2003} & $\begin{array}{l}\text { Natural resources } \\
\text { management plans for the } \\
\text { Sierra de las Nieves } \\
\text { natural park (NRMP) 2003; } \\
\text { Public Use Plan (PUP) }\end{array}$ & $\begin{array}{l}\text { NP. BR. Map (Fig. } 1 \text { ) } \\
\text { and qualitative analysis }\end{array}$ \\
\hline \multicolumn{2}{|c|}{$\begin{array}{l}\text { Consultations and interviews with local and county } \\
\text { authorities (ISSI: Institutions, Stakeholders, Semi- } \\
\text { structured Interview); internet search (2008-2010); } \\
\text { LEADER+(2001- 2006) and PRODER A (2000- } \\
\text { 2006) programmes }\end{array}$} & $\begin{array}{l}\text { Outdoor recreational } \\
\text { initiatives conducted } \\
\text { between } 2001 \text { and } 2006\end{array}$ & $\begin{array}{l}\text { BR. Content analysis; } \\
\text { Table } 4\end{array}$ \\
\hline \multicolumn{4}{|c|}{$\begin{array}{l}\text { Subject: Effects of these policies on the demand for public and private recreational } \\
\text { facilities and on the productive fabric (ordered by scale) }\end{array}$} \\
\hline $\begin{array}{l}\text { PUP User Survey } \\
2008-2010\end{array}$ & \multicolumn{2}{|c|}{ Profile of users of the NP/BR } & \multirow[t]{2}{*}{ NP. In-text references } \\
\hline $\begin{array}{l}\text { Trail traffic counters, } \\
\text { from } 2008\end{array}$ & \multicolumn{2}{|c|}{$\begin{array}{l}\text { Seasonal variations and absolute } \\
\text { numbers of users of the NP/BR }\end{array}$} & \\
\hline $\begin{array}{l}\text { National Institute of Statistics (INE), } \\
\text { Rural Tourism Accommodation } \\
\text { Occupancy Survey 2005-2016 } \\
\text { (interrupted 2009-2011) }\end{array}$ & \multicolumn{2}{|c|}{$\begin{array}{l}\text { Seasonal variations and absolute } \\
\text { numbers of demand for accommodation }\end{array}$} & $\begin{array}{l}\text { AIS NP.In-text } \\
\text { references }\end{array}$ \\
\hline $\begin{array}{l}\text { Active Tourism EnterpriseSurvey } \\
\text { (ATES) (2008-2010) }\end{array}$ & \multicolumn{2}{|c|}{$\begin{array}{l}\text {-Supply of outdoor recreation facilities } \\
\text {-Client profile }\end{array}$} & Andalusia/BR. Table 9 \\
\hline \multirow{3}{*}{$\begin{array}{l}\text { Interviews with stakeholders, institution, } \\
\text { hotel/catering businesses and other } \\
\text { trades, (ISSI) 2008-2010 }\end{array}$} & \multicolumn{2}{|c|}{-Profile of users of private facilities; } & $\begin{array}{l}\text { BR. Tables } 5-6 \text { and } \\
\text { qualitative analysis }\end{array}$ \\
\hline & \multicolumn{2}{|c|}{$\begin{array}{l}\text {-Outdoor activities conducted by clients } \\
\text { of hotels and restaurants }\end{array}$} & $\begin{array}{l}\text { BR. Table } 8 \text { and } \\
\text { qualitative analysis }\end{array}$ \\
\hline & \multicolumn{2}{|c|}{$\begin{array}{l}\text {-Evaluation of hiking as an instrument } \\
\text { for rural development; } \\
\text { - Evaluation of public-sector initiatives }\end{array}$} & $\begin{array}{l}\text { BR. Tables } 11-12 \text { and } \\
\text { qualitative analysis }\end{array}$ \\
\hline $\begin{array}{l}\text { INE: Population census for 1991, } 2001 \\
\text { and } 2011\end{array}$ & \multicolumn{2}{|c|}{$\begin{array}{l}\text { Evolution of numbers employed in } \\
\text { hotels and catering }\end{array}$} & $\begin{array}{l}\text { Municipalities. Maps } \\
\text { (Fig.3 ) and qualitative } \\
\text { analysis }\end{array}$ \\
\hline $\begin{array}{l}\text { Andalusian Regional Ministry for } \\
\text { Tourism, Trade and Sport, 1988-2011 }\end{array}$ & \multicolumn{2}{|c|}{$\begin{array}{l}\text { Evolution of numbers and category of } \\
\text { private hospitality services }\end{array}$} & $\begin{array}{l}\text { Municipalities. Maps } \\
\text { (Figs.4-8 ) and } \\
\text { qualitative analysis }\end{array}$ \\
\hline \multirow{2}{*}{$\begin{array}{l}\text { Projects approved and funded by the } \\
\text { LEADER+(2001- 2006) and PRODER } \\
\text { A (2000- 2006)programmes. }\end{array}$} & \multicolumn{2}{|c|}{$\begin{array}{l}\text { Approved projects for tourism-related } \\
\text { activities }\end{array}$} & $\begin{array}{l}\text { BR. Identified by } \\
\text { CNAE, Table } 7 .\end{array}$ \\
\hline & \multicolumn{2}{|c|}{$\begin{array}{l}\text { Projects aimed at revitalising the rural } \\
\text { environment }\end{array}$} & BR. Table 10 \\
\hline
\end{tabular}

Tab 3. Characteristics and number of surveys carried out of stakeholders, with respect to the relationship between recreational activities and the rural productive fabric (2009-2011).

\begin{tabular}{|c|c|c|c|c|c|}
\hline & & $\begin{array}{l}\text { ISSI } \\
\text { Institutions }\end{array}$ & $\begin{array}{l}\text { ISSI } \\
\text { Tourism-related } \\
\text { facilities }\end{array}$ & $\begin{array}{l}\text { ATES } \\
\text { Active Tourism } \\
\text { Enterprise }\end{array}$ & $\begin{array}{l}\text { PUP user } \\
\text { survey }\end{array}$ \\
\hline \multirow[t]{3}{*}{ Scale } & $A$ & & & 18 & \\
\hline & $\mathrm{M}$ & 33 & & & \\
\hline & BRM & 15 & $\begin{array}{l}19 \text { Catering } \\
28 \text { Accommodation }\end{array}$ & & 345 \\
\hline \multicolumn{2}{|c|}{ Type of survey } & SSI & SSI & $\mathrm{Q}$ & $\mathrm{Q}$ \\
\hline \multirow{2}{*}{\multicolumn{2}{|c|}{ Source, sample }} & & $\begin{array}{l}\text { Register of Tourism in } \\
\text { Andalusia(RTA) }\end{array}$ & $\begin{array}{l}\text { Andalusian Federation of } \\
\text { Active Tourism Enterprises } \\
\text { http://www.andalucia- } \\
\text { activa.com }\end{array}$ & $20 \%$ in person \\
\hline & & \multicolumn{2}{|c|}{$100 \%$ in person. } & $\begin{array}{l}11 \% \text { email questionnaire, } \\
\text { sent to } 100 \% \text { of the } \\
\text { companies (156) }\end{array}$ & \\
\hline
\end{tabular}

Q: Questionnaire, ISSI: Institutions, Stakeholders, Semi-structured Interview; A: Andalusia; M: Málaga province; ATES: Active Tourism Enterprise Survey; BRM: Municipalities in the BR 


\section{Results}

The results obtained are discussed in the same order as in the study aims: first, we analysed the planning of the NP and the actions taken to promote tourism in rural areas, as factors of attraction for the supply and demand of tourist activity. These results are set out below in terms of the qualitative and quantitative characterisation of the demand, the evolution and location of the private facilities made available and the population employed in the tourism sector. Finally, we considered the relationship between hiking (the main outdoor recreation promoted by these policies) and the productive fabric.

\subsection{H1. Constructing the myth: the boost to the supply of outdoor recreational facilities by NP classification and rural development initiatives, as factors assumed to influence the conversion of a rural environment in economic and demographic decline into a tourist destination}

\section{a. The impact of PA classification on the supply of publicoutdoorrecreational facilities}

It is hypothesised that the main factor triggering the area's conversion into a tourist destination was its declaration as a NP in 1989. The focus of the regulations on the management of Pas (NRMP and PUP, Junta de Andalucía, 2003) coincides with the former criterion of "IUCN Protected Areas Category V", which prioritised conservation and environmental education over sustainable development (Dudley, 2008). This approach implicitly focuses on visitors to the detriment of local communities. However, the facilities for outdoor recreation are limited to a network of public trails, for the exclusive use of hikers. These trails are located within the area granted the highest level of protection and also extend into the peripheral Special Regulation Zone. The network of trails is connected with the population centres of the ASI by various forest tracks that, paradoxically, are not included in the PUP (Figure 1). Neither does the PUP incorporate alternative trails for mountain biking, horse ridingor off-road vehicles, or via ferrata for climbing.

Also absent from the PUP are a number of chasms located within the PA, some of major international importance such as the GESM chasm. Due to its fragile state, the use of the latter for caving is subject to specific permits.

In view of the above, we conclude that management of these territories in terms of facilities for outdoor recreation is characterised by a focus on hiking and by the scant attention paid to the repercussions of the NP on the economies of the neighbouring municipalities.

The impact of the BR on territorial management in the study area is unclear, since the applicable legislation in environmental matters is published in the above-mentioned NRMP and PUP (Junta de Andalucía, 2003). On the other hand, these Plans are limited to the NP and therefore exclude almost 80,000 ha of the 100,000 ha included in the BR. However, the creation of the association of municipalities (also mentioned above, see Table 1) has become one of the most active stakeholders in the NP in terms of socioeconomic initiatives. Due to this de facto disassociation of the environmental policies, we analyse their activity in the following section.

\section{b. Public initiatives to promote tourism in the rural environment}

As can be seen in Table 4, institutions of all dimensions (regional and provincial authorities, the technical management of the NP, the rural development group (RDG) associated with the LEADER programme, the Association of Municipalities (AM) and individual town councils) have implemented initiatives to promote rural tourism. Andas in the NP, these initiativesare mainly based on hiking, which is free of charge.

The initiatives taken are mostly informative (the publication of guides, brochures and web pages accounts for $49 \%$ of the activity), and less emphasis is placed on management (signposting and trail marking accounts for $19 \%$ of the activities, and maintenance for a further $14 \%$ ). 
Tab 4. Tourism-related actions taken by institutions in the NP, ASland BR. Sources: ISSI: Interviews with institutional authorities; Web sites. See Tables 2 and 3.

\begin{tabular}{|l|c|c|c|c|c|c|}
\hline \multicolumn{1}{|c|}{ Action taken } & $\begin{array}{c}\text { Regional } \\
\text { (AC) }\end{array}$ & Provincial & $\begin{array}{c}\text { County } \\
\text { (RDGandAM) }\end{array}$ & Local & Total (n) & $\%$ \\
\hline $\begin{array}{l}\text { Organisation of } \\
\text { activities }\end{array}$ & 1 & 3 & 3 & 13 & 20 & 14 \\
\hline Guides & 0 & 3 & 4 & 10 & 17 & 11 \\
\hline $\begin{array}{l}\text { Publication of } \\
\text { brochures }\end{array}$ & 1 & 4 & 4 & 20 & 29 & 20 \\
\hline Web pages & 1 & 4 & 3 & 18 & 26 & 18 \\
\hline $\begin{array}{l}\text { Trail signposting and } \\
\text { marking }\end{array}$ & 1 & 3 & 1 & 13 & 18 & 19 \\
\hline Trail maintenance & 1 & 1 & 1 & 12 & 15 & 14 \\
\hline Total actions (n) & 6 & 21 & 17 & 92 & 142 & 100 \\
\hline$\%$ & 4 & 14 & 11 & 64 & & 100 \\
\hline
\end{tabular}

AC: Autonomous Community; RDG: Rural Development Group/LEADER; AM: Association of Municipalities/BR.

The content of the institutional activities proposed in municipal web pages also illustrates the aim of supplying a charge-free public service, which is in line with the goals of the IUCN. One such goal is to provide environmental education to raise awareness among the local population of the park's values and to encourage recreational use. However, this activity is not intended to identify entrepreneurial possibilities, but is aimed at groups unrelated to the business world (for example, in the form of free visits for schoolchildren or the elderly). Similarly, sports activities are organised by local non-profit associations and by specialised companies, but do not have a business bias. Therefore, the main conclusion we draw from the contrast between the organisational activities carried out and the definitions set out above is the non-existent diversification of these activities, which are focused almost exclusively on hiking, and their decoupling from direct economic exploitation.

\subsection{Monitoring the effects of these policies on the supply and demand of public and private recreational facilities}

In theory, the initiatives described should result in the constitution of a demand-supply system of tourism-related activities.

a. Low-level, complex demand: visitors, hikers, users of public and private recreational facilities

Analysis of the data obtained from the above-described sources and procedures reveals the following quantitative and qualitative characterisation of visitors to the study area:

Segment 1: Users of PUP trails: measured by trail traffic counter data, around 12,000 users per year. According to the PUP Users' Survey (see Table 3), this population group is very homogeneous; 94\% come from nearby urban areas (Sevilla, Malaga, Costa del Sol, Campo de Gibraltar, potential user source of about two million inhabitants). None are of foreign nationality. These proximity visitors make almost no use of organised travel (2\%), often travel as a group, mainly with friends (43\%) or family/partners (26\% and $23 \%$, respectively). The gender distribution is equally balanced. By age, a majority are young to middle aged (53\%), and only $2 \%$ are aged over 60 years. Almost all travel to the NP by private transport (98\%). The majority of visits take place during weekends and bank holidays (80\%) and there are considerable seasonal variations, with $49 \%$ of visits made during the winter months (especially following episodes of snowfall), followed by the spring (29\%) and autumn (17\%). Only $5 \%$ of visits take place during the summer. 
Segment 2: Clients of active tourism companies. The source used (ATE survey, Table 3 ) does not state visitor numbers, but does provide information on their profiles. For the companies sited in other Andalusian provinces, their clients are mainly groups of young friends (aged 25-40 years) and organised groups of schoolchildren. These visits mainly take place in the autumn and spring. Companies based on the Costa de Sol and in Ronda usually have a high percentage of clients of foreign origin, mainly from the European Union, especially when the company itself is of foreign origin. Two different preferences can be watched in the summer season, families practice horse riding while older clients (65-80 years) request off- road $4 \times 4$ routes. These clients as a whole, therefore, present a more diverse pattern of profiles, reflecting the broader spectrum of outdoor activities performed.

Segment 3: Clients of private recreational facilities (accommodation and catering). As indicated in section 5.3. we only have quantitative data for users of accommodation in the ASI (overnight stays), according to which during the period from 2005 to 2016 an annual average of 4,650 visitors made 20,774 overnight stays, representing 4.45 overnight stays per person. In this period, the 2007 economic and financial crisis had a severe impact on visitor numbers, provoking a sharp decrease in weekend employment, from peak levels of $66-75 \%$ between 2005 and 2007 to peaks of $33-45 \%$ between 2012 and 2017. The greater presence of these establishments in the southern sector of the study area (discussed below) explains the summer-season bias of these visitors, with a maximum in August and a minimum in January. Overall, during seven months of the year, even at weekends, the occupancy rate is below $20 \%$.

As shown in Table 5, the social grouping of their clients is very homogeneous and similar to that of the PUP users. A notable feature is the low presence of visitors arriving as part of an organised group. In contrast, Table 6 shows there are considerable variations in visitors' place of origin and preferred season. These factors vary according to the location of the establishment and the importance of the functions offered (i.e. accommodation and catering) with respect to their local contexts.

Tab 5. Social grouping of clients of tourist and commercial establishments. \% of all interviews conducted for each category of establishment. Source: ISSI, see Table 3

\begin{tabular}{|l|c|c|c|c|c|c|}
\hline & \multicolumn{7}{|c|}{ Social grouping of clients } \\
\hline $\begin{array}{l}\text { Category of } \\
\text { establishment }\end{array}$ & Families & $\begin{array}{l}\text { Groups of } \\
\text { young } \\
\text { people }\end{array}$ & Couples & $\begin{array}{l}\text { Organised } \\
\text { groups }\end{array}$ & $\begin{array}{l}\text { Individual } \\
\text { hikers }\end{array}$ & Total \\
\hline Accommodation & 22.89 & 24.10 & 30.12 & 10.84 & 12.05 & 100 \\
\hline Catering & 23.08 & 26.92 & 25.00 & 9.62 & 15.38 & 100 \\
\hline
\end{tabular}

Tab 6. Relationship between the area's inclusion within the PUP and the seasonal cycle of visits to tourist establishments. \% of all interviews conducted for each category of establishment. Source: ISSI, see Table 3

\begin{tabular}{|l|c|c|c|c|c|c|c|c|c|c|}
\hline & \multicolumn{4}{|c|}{ Accommodation } & \multicolumn{5}{c|}{ Catering } \\
\hline & Winter & Spring & Summer & Autumn & Total & Winter & Spring & Summer & Autumn & Total \\
\hline Non-PUP & 13 & 26 & 44 & 18 & 100 & 37 & 5 & 32 & 26 & 100 \\
\hline PUP & 23 & 36 & 9 & 32 & 100 & 29 & 35 & 6 & 29 & 100 \\
\hline Combined & 16 & 30 & 31 & 23 & 100 & 35 & 15 & 24 & 27 & 100 \\
\hline
\end{tabular}

A significant feature revealed by our analysis is the different patterns of use of these establishments, according to the municipality's inclusion or otherwise in the PUP. For accommodation providers located in municipalities unaffected by the PUP, the spring and summer are the seasons of maximum occupancy, reflecting the greater proportion of visitors staying in or near the Costa del Sol; these visitors are predominantly non-hikers, of foreign origin and are having a summer holiday. On the contrary, the establishments located in municipalities subject to the PUP report lower occupation rates in the summer, which tallies with the low user 
numbers detected in this period by the trail traffic counters. With regard to catering establishments, a similar pattern is observed except in the winter, when those located in municipalities with no PUP report having maximum visitor numbers, reflecting their closer links with the local population and the benefits derived from Christmas celebrations.

$b$. The evolution of the spatial distribution of the supply of private recreational facilities. Why do public trails not always lead to the provision of private services?

Analogously to the procedure followed for the public offer of outdoor recreational facilities (and in accordance with our bibliographic review), we find that rural development programmes play a major role in stimulating tourism-related activities (Table 7). Between 2001 and 2006, 203 projects were approved for a total value of $€ 8,619,442$, an average of $€ 42,395$ per project. Of the latter sum, almost $€ 30,000$ was contributed by the businesses concerned. Hotel and catering projects accounted for almost a quarter (24\%) of this funding, evenly distributed between them, while a much lower proportion was obtained by campsites.

Tab 7. Allocation of funding (public and private) for projects approved under the LEADER + and PRODER A programmes (2001-2006) by the Sierra de las Nieves RDG. Source: AGDR 2000-2006: Projects approved by the Sierra de las Nieves AGDR

\begin{tabular}{|l|l|c|c|}
\hline \multicolumn{2}{|l|}{ CNAE codes (1, 2 and 3 digits) } & Total $€$ & $\%$ \\
\hline Agriculture & & 652,378 & 7.57 \\
\hline Manufacturing & & $4,307,296$ & 49.96 \\
\hline \multirow{5}{*}{ Services } & Retail and repairs & 341,544 & 3.96 \\
\cline { 2 - 4 } & Other social and service activities & $1,170,873$ & 13.58 \\
\cline { 2 - 4 } & Hotels & 930,530 & 10.8 \\
\cline { 2 - 4 } & Campsites and similar & 121,897 & 1.41 \\
\cline { 2 - 4 } & Restaurants & $1,046,488$ & 12.14 \\
\cline { 2 - 4 } & & $3,611,332$ & 41.89 \\
\hline Total & & $8,619,442$ & 100 \\
\hline
\end{tabular}

The results corresponding to the location and evolution of private recreational facilities include their association with the PUP trail network, as an indicator of the impact produced by the supply of outdoor recreation facilities.

Figure 3 shows that the municipalities containing public outdoor recreation facilities linked to the NP are those which present the least growth in employment in hotels and restaurants. This finding, together with the content of Table 6 , leads us to conclude that although the existence of the PUP boosts tourist demand, this increase is not sufficient to strengthen growth in employment in tourism-related industries. 


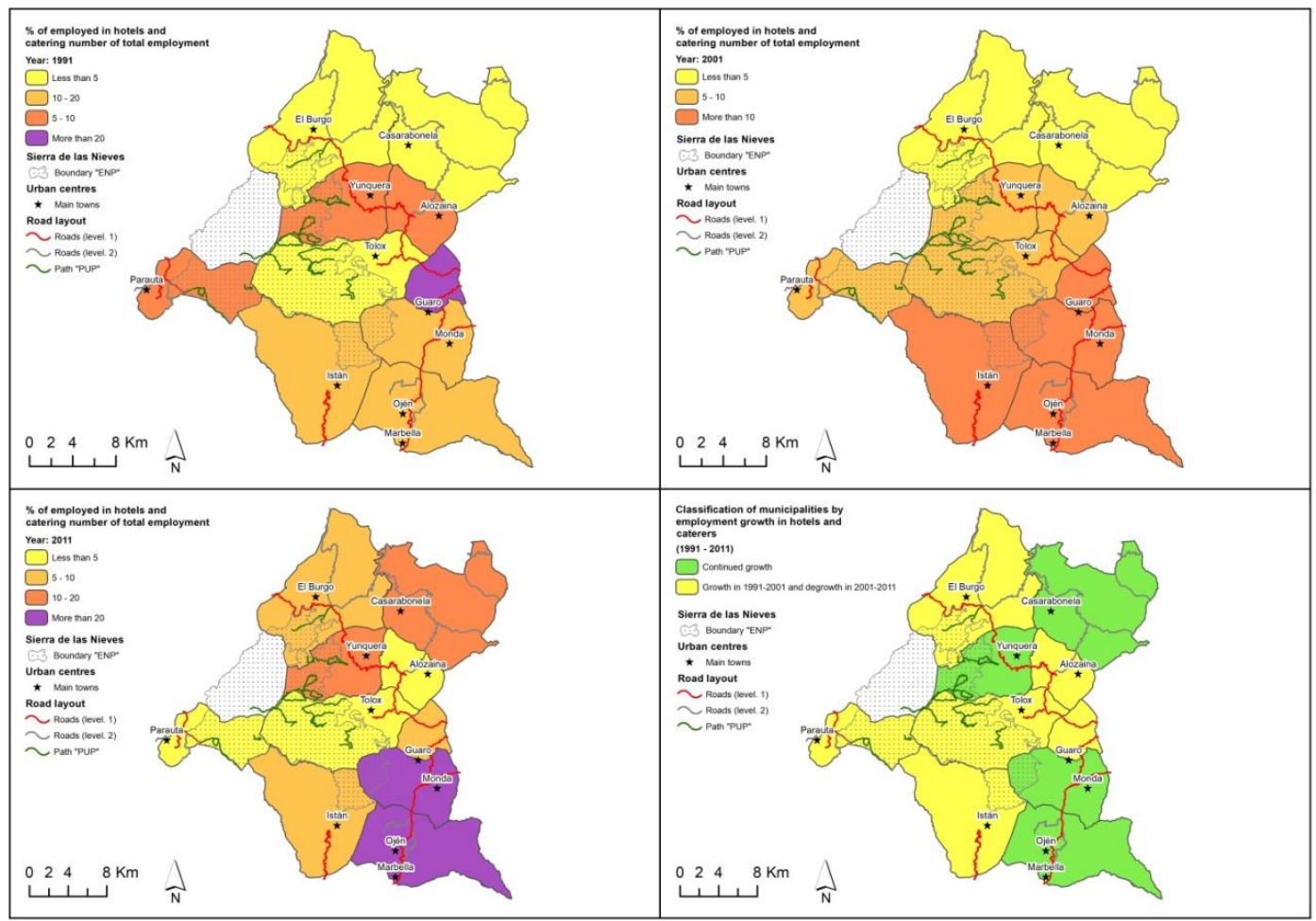

Fig 3. Employment in hotels and caterers as \% of total employment (1991-2011). Source: Population censuses 1991, 2001 and 2011

This weak impact on employment figures is in line with the evolution of the different suppliers of private recreational facilities. Thus, the number of hotels recorded (Fig. 4) is consistent with the low number of overnight stays referred to above, resulting in a homogeneous distribution of two hotels per municipality, regardless of the application or otherwise of the PUP. It is striking, moreover, that the only municipality in which there are two hotels does not have private recreational facilities.

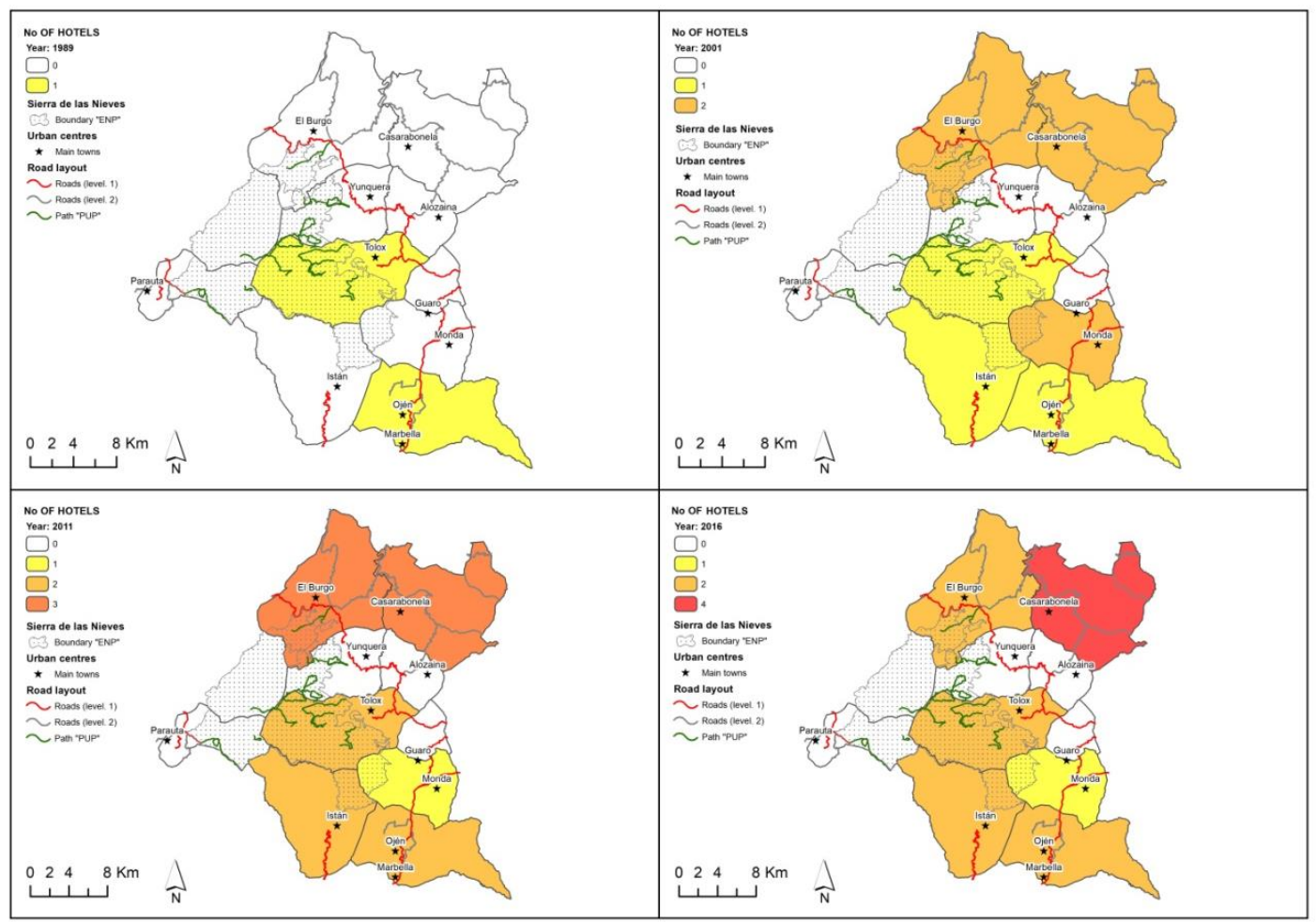

Fig 4. Evolution of the number of hotels 1989-2016. Source: Department of Tourism, Trade and Sport, Regional Government of Andalusia, consulted in SIMA: Andalusian Municipality Information System 
Figures 4 and 5 reveal significant differences in the responses of rural social structures to the opportunity of providing tourism-related activities. While campsites were observed in only four municipalities, there was intense, sustained growth throughout the study period in the provision of rural accommodation for tourists, a feature that is directly linked to rural social structures.

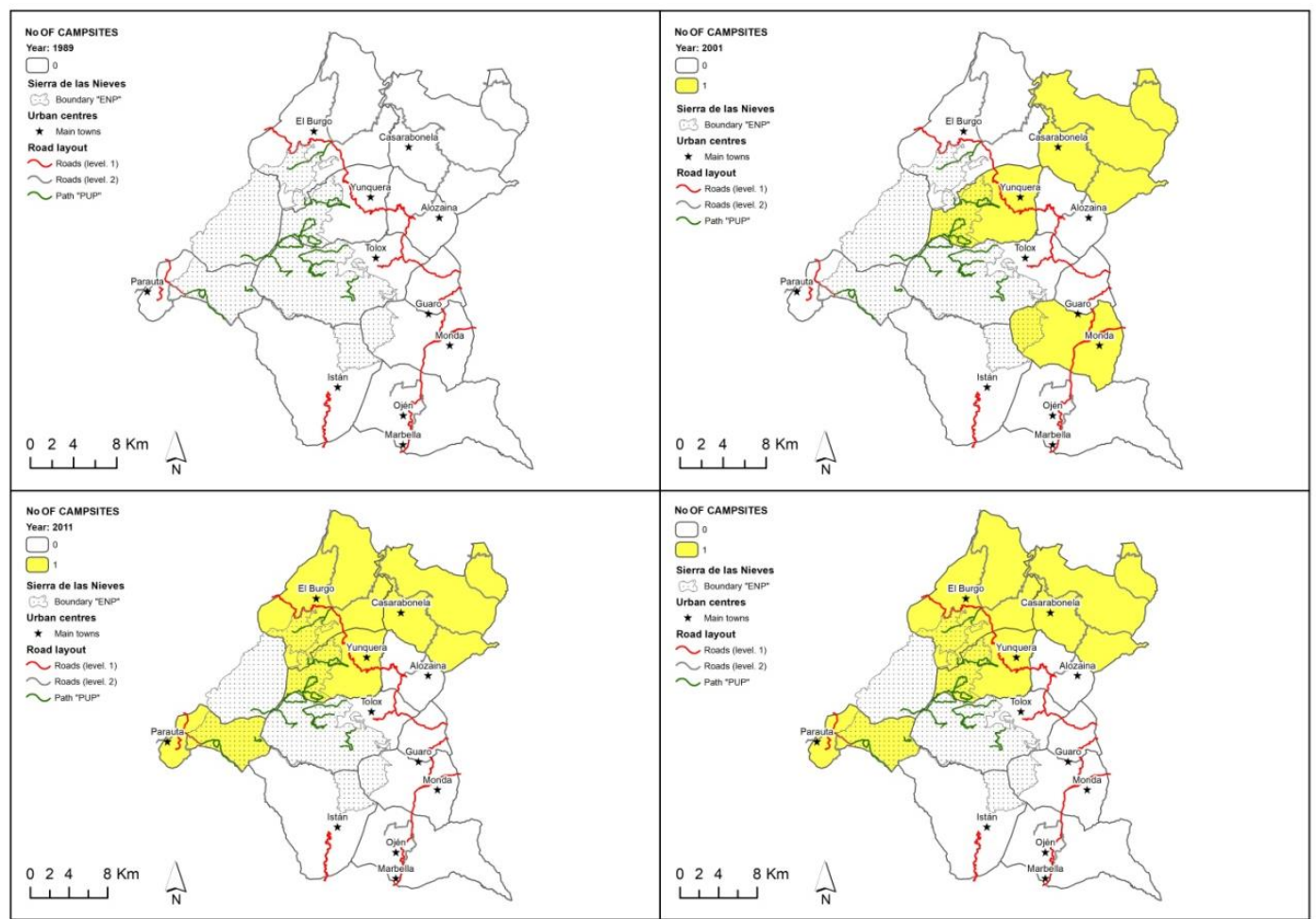

Fig 5. Evolution of the number of campsites 1989-2016. Source: Department of Tourism, Trade and Sport, Regional Government of Andalusia, consulted in SIMA: Andalusian Municipality Information System]

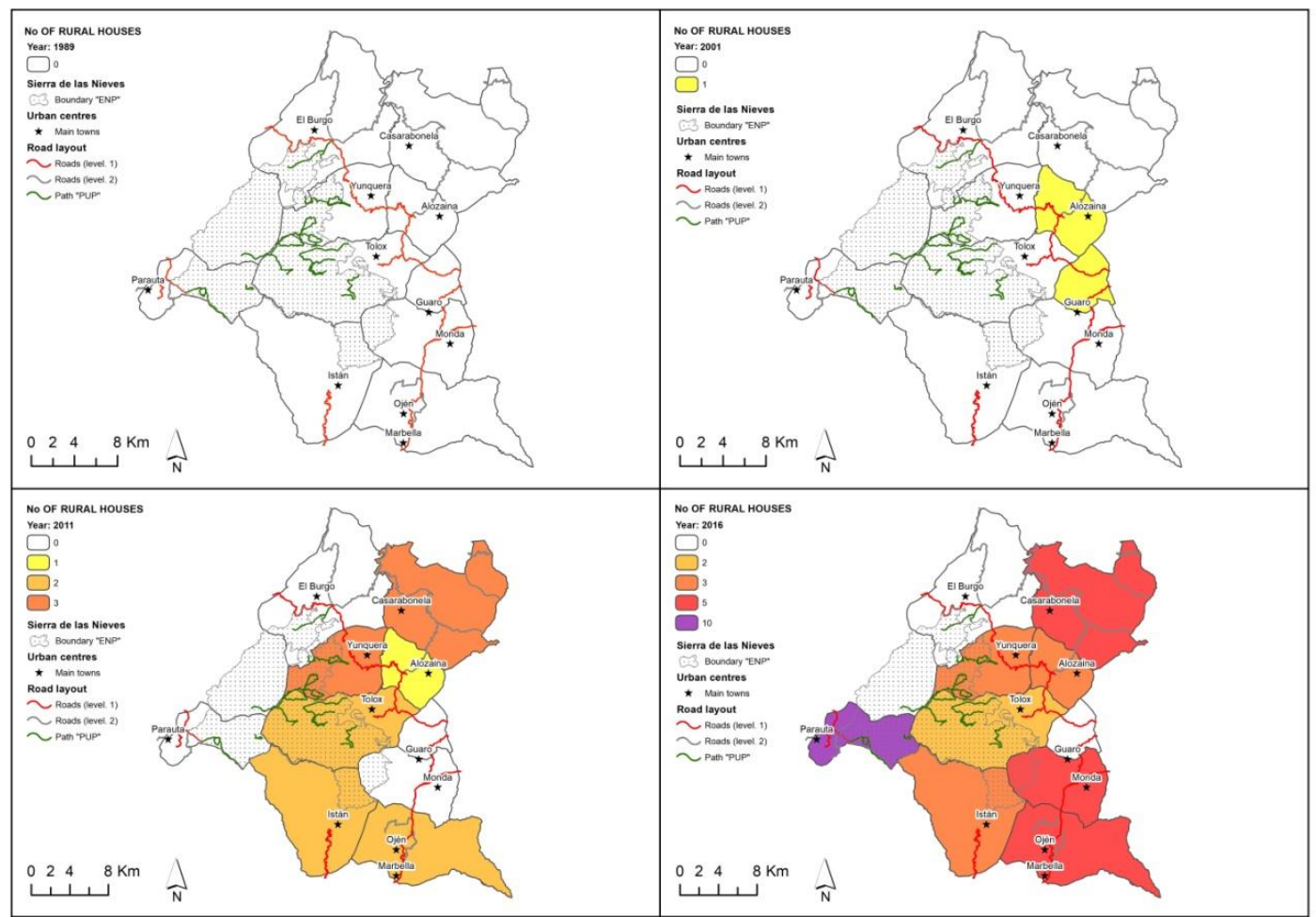

Fig 6. Evolution of the number of rural houses for tourists 1989-2016. Source: Department of Tourism, Trade and Sport, Regional Government of Andalusia, consulted in SIMA: Andalusian Municipality Information System 
Finally, our analysis of tourist apartments (Fig.7) and restaurants (Fig. 8) shows that these private facilities clearly reflect the fragmentation of the visitor profiles described in the previous section. The large number of apartments is explained in Tolox by the presence of a historic spa, and in Ojén by its proximity to the Costa del Sol. The evolution of the number of restaurants confirms the dissociation between their clients and those of hotels, with the former having a greater number of establishments, both near the Costa del Sol and in municipalities subject or otherwise to the PUP (Yunquera and Casarabonela, respectively).

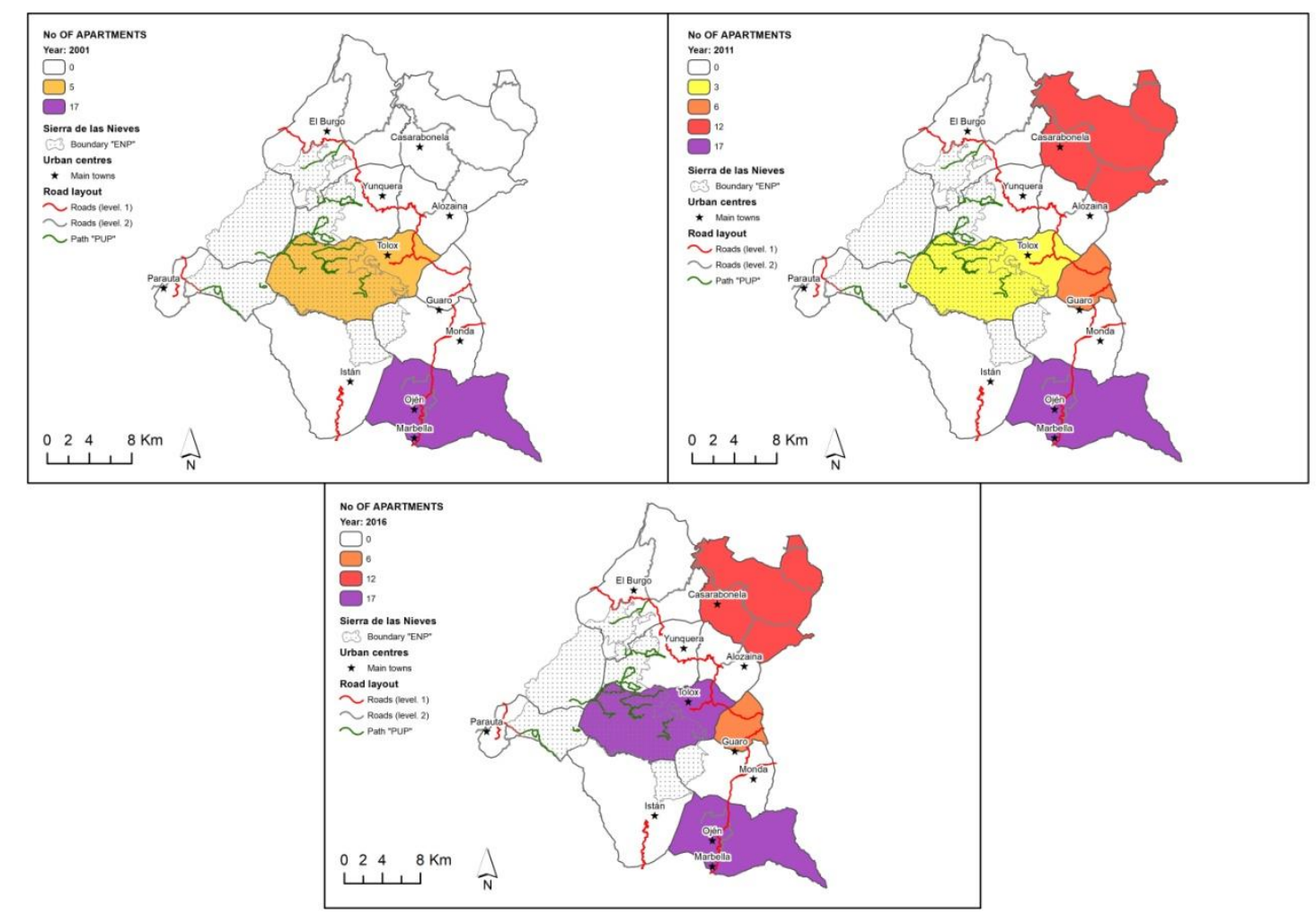

Fig 7. Evolution of the number of apartments and holiday homes 2001-2016. Source: Department of Tourism, Trade and Sport, Regional Government of Andalusia, consulted in SIMA: Andalusian Municipality Information System

According to these results, the extent to which public outdoor recreational facilities attract private investment seems to present a random pattern. While there is least interest in El Burgo in providing private facilities for tourists, and most interest in Casarabonela, located outside the NP, Yunquera, which also has public outdoor recreational facilities, presents the greatest increase in private services; however, it has no hotels. In contrast, rural accommodation is the service preferred by the tiny village of Parauta, which is also the most popular location for public outdoor recreational facilities. Furthermore, the evidence shows that the private services that are most rapidly expanding are those which generate least employment (i.e. rural houses and apartments); these facilities, therefore, may be considered as providing a supplement to the family income. 


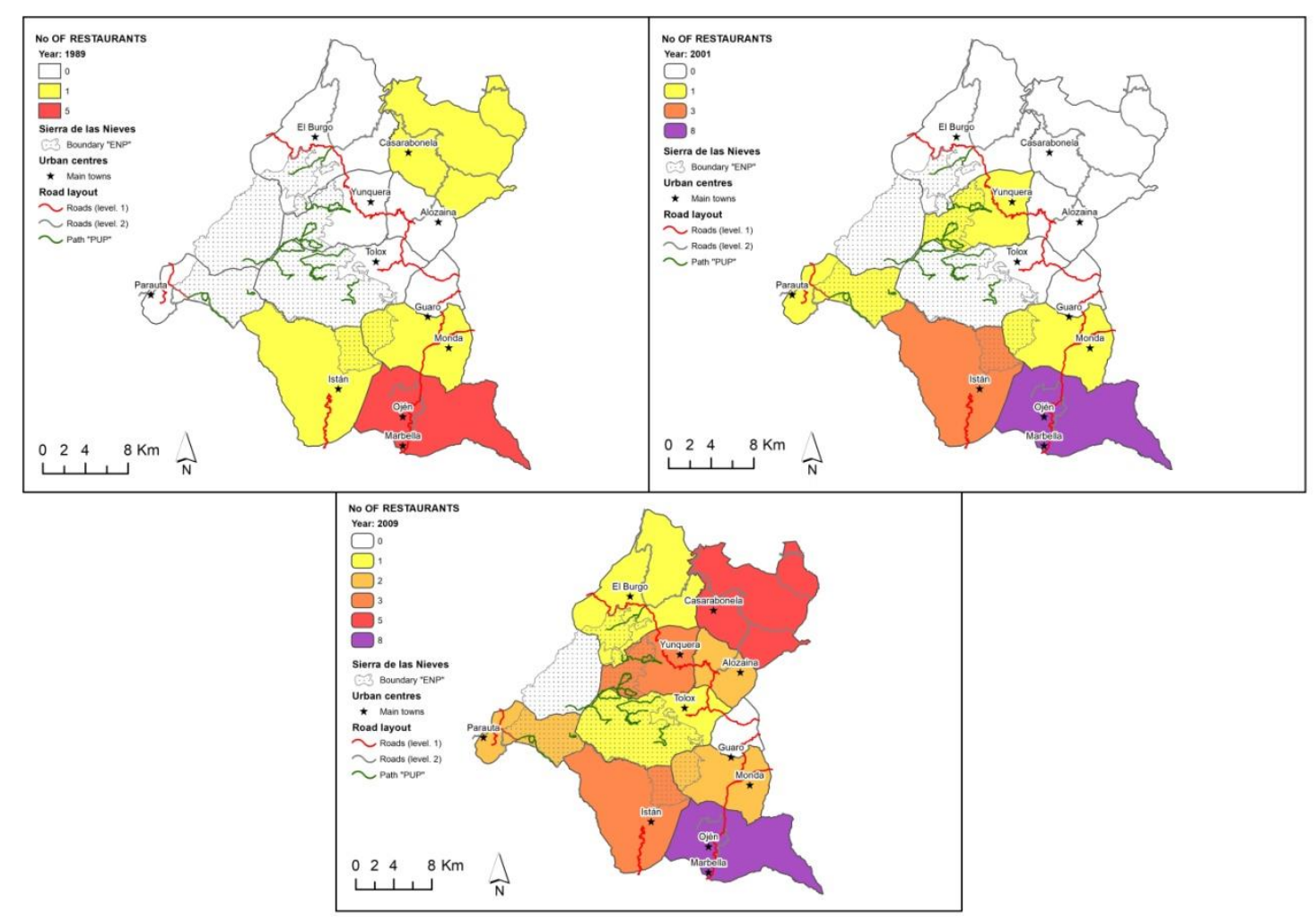

Fig 8. Evolution of the number of restaurants 1989-2009. Source: Department of Tourism, Trade and Sport, Regional Government of Andalusia, consulted in SIMA: Andalusian Municipality Information System]

\section{c. The lion's share of outdoor recreation facilities, for hikers}

As explained in the bibliographic review and methodology sections, outdoor recreation is one of the forms of economic diversification induced by the area's declaration as a PA and by rural development policies. In this regard, it is interesting to note that today, twenty years after the creation of the NP, there are no active tourism companies based in the study area, and that their presence has always been erratic, ranging from one in 2007 to five in 2011 to none in 2012 . Therefore, the active tourism companies detected are all externally based, which reflects the disconnection between human resources, equipment and territorial resources in facilitating most of the outdoor recreation activities described. Conversely, the institutional involvement observed is limited to fostering a single activity, hiking, which is associated with little or no commercial activity. Therefore, our analysis focuses on the results obtained from this part of the study (i.e. the information obtained from interviews with stakeholders and from the ATE survey) to determine the relationship between outdoor recreational practices, on the one hand, and the customer base of private establishments, on the other.

Table 8 presents the data supplied by the owners of private establishments about the outdoor recreational practices of their clients. This table shows that many users do not contact active tourism companies but that they do visit the towns and places of interest in the area, which highlights the analyst's difficulty in separating hiking as a recreational activity from other types of visit conducted on foot. In contrast, the outdoor recreation activities detailed in the literature are practised by very few clients of the hospitality industry in the area affected by the NP (15\% of hotel clients and $5.5 \%$ of restaurant clients). 
Tab 8. Tourism activities conducted by clients of hotels and restaurants (\% of total establishments). Source: ISSI, see Table 3

\begin{tabular}{|l|c|c|}
\hline & Hotels & Restaurants \\
\hline Short walks & 42.31 & 50.00 \\
\hline Visits to towns/villages and other places of interest & 40.38 & 44.44 \\
\hline Active tourism activities & 15.38 & 5.56 \\
\hline No activity & 1.92 & 0.00 \\
\hline Total & 100 & 100 \\
\hline
\end{tabular}

Table 9 details these practices, contrasting the data obtained from local hotels and restaurants with those provided by the survey of active tourism companies.

Tab 9. Outdoor recreationactivities in the BR. Source: ISSI and ATE surveyS, see Table 3

\begin{tabular}{|l|c|c|c|}
\hline & \multicolumn{2}{|c|}{$\begin{array}{c}\text { Companies' perceptions of } \\
\text { customer preferences (1) }\end{array}$} & $\begin{array}{c}\text { Active tourism activities } \\
\text { performed in the study area (2) }\end{array}$ \\
\hline Active tourism activity & Restaurants & Hotels & 7 \\
\hline Speleology & 7 & 4 & 15 \\
\hline Canyoning & 2 & 3 & 4 \\
\hline Rock climbing & 3 & 3 & 4 \\
\hline Mountaineering & 3 & 4 & 10 \\
\hline Hiking & 55 & 47 & 11 \\
\hline Horse riding & 9 & 15 & 19 \\
\hline Mountain biking & 11 & 14 & 8 \\
\hline Cycling & 0 & 0 & 0 \\
\hline Quads & 3 & 3 & 15 \\
\hline Off-road4x4 & 3 & 3 & 0 \\
\hline Hunting & 2 & 3 & 7 \\
\hline River fishing & 2 & 1 & 4 \\
\hline Clay pigeon shooting/Archery & 0 & 0 & 100 \\
\hline Other & 0 & 0 & \\
\hline & 100 & 100 & \\
\hline
\end{tabular}

(1) \% of all responses by hotel/restaurant owners;

(2) \% of all responses by companies consulted

This table also shows that more than half of the hotel and restaurant customers are hikers, while this is true of only $10 \%$ of the customers of active tourism companies. The reason for this low demand is that hiking can be performed independently and without any external facilities. Another significant factor is the weak relationship between the users of hotel/restaurant facilities and the customer base of active tourism companies; thus, activities that are demanded by $10-15 \%$ of the latter customers, such as canyoning, $4 \times 4$ off-road exploring, clay pigeon shooting and archery, are practised by fewer than $5 \%$ of hotel/restaurant users. Only tourists interested in horse riding or mountain biking are equally represented among all stakeholders, a fact that contrasts with the paucity of trails available for these pursuits in the PUP. This list of activities is incomplete, lacking some that are included in the open responses made to the questionnaire by tourism entrepreneurs, who identify a small number of clients interested in specific activities such as birdwatching or mushroom gathering. Finally, in the theoretical framework it is difficult to identify 
motorcycling as a separate outdoor recreation, although restaurants have reported seeing growing numbers of off-road motorcyclists among their customers.

d. What role has been played by bottom-up lines of action in creating the supply of private-sector services?

As shown in Table 10, the priority attention theoretically expected of the lines of action to transform collective attitudes regarding local socioeconomic change has not in fact been achieved. In this respect, lines 1.4. 'Social actions and territorial cohesion', 1.5. 'Training and employment incentives' and 1.6. 'Technical support for rural development' actually received the lowest levels of funding, with $6.3 \%, 3.8 \%$ and $6.8 \%$, respectively (see Table 7 ). In fact, the policies that received most funding were the lines of action related to public investments not requiring a proactive attitude by local communities.

Tab 10. Distribution (\%) of the funding obtained for different lines of action from the LEADER+ and PRODER A (2000 2006) programmes.

\begin{tabular}{|l|c|c|c|}
\hline Line of action & LEADER + & PRODER A & Total \\
\hline 1.2. Infrastructure improvements & 64.24 & 31.26 & 60.31 \\
\hline $\begin{array}{l}\text { 1.3. Enhancement to natural heritage and } \\
\text { environmental values }\end{array}$ & 18.77 & 23.09 & 19.28 \\
\hline 1.4. Social actions and territorial cohesion & 6.32 & 0.00 & 5.56 \\
\hline 1.5. Training and employment incentives & 3.87 & 0.00 & 3.41 \\
\hline 1.6. Technical support for rural development & 6.81 & 30.59 & 9.64 \\
\hline (1) & 0.00 & 15.05 & 1.79 \\
\hline & 100 & 100 & 100 \\
\hline
\end{tabular}

(1) LEADER + Community Initiative "Approximation of new technologies to the rural population to overcome endemic isolation"

\subsection{Deconstructing the myth: the economic impact of outdoor recreation, according to stakeholders}

Hiking is the most popular outdoor recreation among clients of private tourist services, which is in line with initiatives based on environmental and rural development policies. In the present study, therefore, the questionnaire for users of the PUP trails and for stakeholders includes items intended to contrast the theoretical view that hiking has a positive impact on the local productive fabric with stakeholders' assessments of the real economic impact produced, both on the local economy and on the revenues obtained by private tourist facilities.

Practically, all of the respondents (institutions and tourism companies) acknowledge that hiking is the main outdoor recreation activity in Sierra de las Nieves. They also agree in their response to the question, "Do you think hiking benefits the incomes of the local population?", with 95\% of the institutions and $100 \%$ of the owners of tourist establishments (hotels and restaurants) agreeing that although the presence of hikers could increase the income of the local population, this potential has not materialised. The key to this negative assessment can be inferred from Tables 11 and 12. Although Table 11 shows there is a greater proportion of hikers in the municipalities affected by the PUP, Table 12 clarifies that this greater presence is accompanied by a lower level of spending per capita than that of other customers. This finding is in line with the results of the PUP user questionnaire, according to which $75 \%$ of the hikers surveyed have not used any of the private services offered; they have neither used accommodation, nor eaten in restaurants nor made any purchases in local shops. 
Tab 11. Opinions of hotel and restaurant owners on the percentage of their customers who practise hiking. Source: ISSI, see Table 3

\begin{tabular}{|l|c|c|c|c|c|c|c|c|}
\hline & \multicolumn{4}{|c|}{ Hotels } & \multicolumn{4}{c|}{ Restaurants } \\
\hline & $<20 \%$ & $21-50 \%$ & $>51 \%$ & Total & $<20 \%$ & $\begin{array}{l}21- \\
50 \%\end{array}$ & $>51 \%$ & Total \\
\hline Non-PUP & 59 & 24 & 18 & 100 & 86 & 0 & 14 & 100 \\
\hline PUP & 25 & 13 & 63 & 100 & 33 & 50 & 17 & 100 \\
\hline Combined & 48 & 20 & 32 & 100 & 62 & 23 & 15 & 100 \\
\hline
\end{tabular}

Tab 12. Opinions of hotel and restaurant owners on the amount spent by their customers: hikers vs. non-hikers. Source: ISSI, see Table 3

\begin{tabular}{|c|c|c|c|c|c|c|c|c|}
\hline & \multicolumn{4}{|c|}{ Hotels (\%) } & \multicolumn{4}{|c|}{ Restaurants (\%) } \\
\hline & $\begin{array}{l}\text { More } \\
\text { than non- } \\
\text { hikers }\end{array}$ & $\begin{array}{l}\text { The same } \\
\text { as non- } \\
\text { hikers }\end{array}$ & $\begin{array}{l}\text { Less than } \\
\text { non-hikers }\end{array}$ & Total & $\begin{array}{l}\text { More } \\
\text { than non- } \\
\text { hikers }\end{array}$ & $\begin{array}{l}\text { The same } \\
\text { as non- } \\
\text { hikers }\end{array}$ & $\begin{array}{l}\text { Less } \\
\text { than } \\
\text { non- } \\
\text { hikers }\end{array}$ & Total \\
\hline Non-PUP & 16 & 47 & 37 & 100 & 0 & 30 & 70 & 100 \\
\hline PUP & 13 & 0 & 88 & 100 & 0 & 0 & 100 & 100 \\
\hline Combined & 15 & 33 & 52 & 100 & 0 & 17 & 83 & 100 \\
\hline
\end{tabular}

The respondents mention several possible causes of the above-mentioned spending differences between hikers and non-hikers. Spending patterns can be classified in two ways: according to the dependence on public or private factors, and according to the supply and demand components. In the first of these respects, the respondents generally agree that the instruments employed to publicise the merits of the area are insufficient; that there are significant distances between public and private facilities; that the NP trail network is inadequate in many of the municipalities; that more visitor centres are needed; and that the trails outside the NP are poorly maintained and signposted.

Regarding private initiatives, there is general agreement that the local business community should offer more activities, an insufficiency that is identified both as a cause and as a consequence. Among the endogenous causes of this insufficiency, there is said to be a lack of local initiatives, because "only outsiders realise the economic possibilities offered", while more dynamic patterns of tourist promotion are observed in comparable destinations such as Cazorla and Grazalema.

On the other hand, the existence of weak demand by trail users for recreational facilities is confirmed by data from the PUP user survey. This problem is identified by all stakeholders as the main reason why the popularity of hiking is not boosting the local economy. According to these respondents, hikers constitute a less attractive demand segment than other visitors (see profile 3 in Section 2.1), due to their low levels of spending. This relative parsimony is due to various reasons. Firstly, it is the question of age and social status: many hikers are young families, with children, with low purchasing power. In consequence, they spend little at the destination, and often bring with them the main products needed (basically food). This profile matches the sharp increase observed in renters of rural accommodation. However, this categorisation is contradicted by other respondents, such as owners of private facilities located in municipalities closest to the area covered by the PUP, who state that hikers form an important or very important segment of their clientele. 


\section{Conclusions and Discussion}

1.- Regarding the initial study hypotheses, our analysis of the relationships observed between tourism, PAs, rural development initiatives and rural social structures leads us to draw the following conclusions:

a) There is little diversification of the outdoor recreation activities offered. Those other than hiking must be performed outside the NP, in the peripheral BR area, and are organised by nonlocal companies. This finding corroborates Fernández and Santos (2010), who found the Sierra de las Nieves NP to be among the least dynamic of all those in Andalusia in terms of the creation of active tourism companies. Public initiatives have also been concentrated on hiking, both within and beyond the NP.

b) The activities offered reflect a pattern of demand that is low in volume and diffuse in nature. Thus, a majority of NP users are hikers, i.e. day visitors who spend little, while it is the users of private recreational facilities who are attracted by rural goods and services. In line with this pattern of use, the growth of private tourist facilities has also been weak, with a clear predominance of rural accommodation and an absence of active tourism companies. Hence, there has been little effect on local employment in the tourism sector. These findings refute certain methodological approaches according to which the declaration of a PA has great potential for the area in question (Martínez \& Romero, 2003; Anton et al., 2008; Pulido, 2008; Reinoso \& Sancho, 2011) and coincide, in terms of the limited diversification of outdoor recreational facilities, with those obtained by Baños \& Rico (2016) in their study of inland Alicante and with the weak dynamisation capacity in general argued by Mulero (2005). Only Ballesteros (2014), whose study addressed a different type of natural environment, that of the Alicante coast, reports a significant presence of active tourism companies. Moreover, although the growth in the number of hotels and restaurants is the most common indicator used to determine the impact of an area's declaration as a NP (Serrano \& Aparicio, 2017), other researchers agree that there is an imbalance between the supply of recreational facilities and the demand. In consequence, such facilities have little capacity to stimulate the economy (Benito et al. 2011, with respect to Guadalajara; Leco, et al., 2015 in Monfragüe; Capdepón, 2015, in Alicante; Cortijo, 2016, in Las Villuercas). Among studies that have focused on the impact of LEADER initiatives on tourism demand, Pillet (2011) identifies an increase in regional GDP following growth in rural tourism in Castilla-La Mancha, while García (2011) claims that such programmes do generate additional income, although this study only measures their effects on the supply of accommodation and other recreational facilities, without examining the real demand for them. Finally, a stronger growth in the supply of rural accommodation, in comparison with more labour-intensive facilities, has been reported by Etxano (2009) in the Basque Country and by Fernández \& Santos (2010) in Andalusia.

c) The influence of public recreational facilities in stimulating demand for private ones appears to follow a random pattern. Although the levels of all kinds of private tourism-related services have risen in each municipality in the study area, there is no evident spatial relationship between public and private services. In this regard, the main contribution of our analysis refers to the scale of the intervention made; local measures highlight the disparity of the effects on the productive fabric between some municipalities and others within the ASI and the BR. This finding corroborates the results obtained by Sánchez et al. (2017) in Cáceres, and contrasts with others in which the study unit considered is the set of all natural parks, in which case the positive evaluation made of the overall positive effects produced by the PA declaration conceals local differences (Fernández \& Santos, 2010; Serrano \& Aparicio, 2017).

d) In view of these considerations, we conclude that the initiatives applied to the study area, a mountain region experiencing demographic and economic decline, to make it a popular tourist destination, have only limited potential for success. This limitation arises from the following problems and mistakes that have beset the management of the PA and its programmes for rural development:

\section{d.1. A concentration of rural development policy initiatives focused on:}


a) hiking, an activity that produces very little impact on the productive fabric, since it does not require business structures and is associated with a visitor profile with low levels of spending at the destination;

b) publicising and promoting the study area by means of relatively ineffective instruments, which reach neither visitors nor tourist establishments.

\section{d.2. A lack of synergy:}

a) between environmental and rural development policies; the availability of outdoor recreational facilities associated with the NP has not led to the consolidation of a productive industrial fabric based on tourism in the municipalities in which the park is located; conversely, the nature of the private facilities does not seem to respond to local employment needs, reflecting a disconnection between the PUP and the corresponding population centres.

b) between the different segments of tourist facilities offered, which focus on specific demands related to subsectors (catering vs. accommodation) and location (proximity to the NP or to the Costa del Sol) and therefore are uncoordinated in their expectations.

d.3. Discontinuity in the financing of public initiatives and, consequently, in their materialisation in terms of maintenance and personnel.

Numerous studies concur that the PAs and the LEADER programme have only a limited capacity to reverse trends of demographic and economic decline. Thus, Bachiller (2012) criticises the low level of compensation received by the woodland associations of Soria for the public use made of these territories. Similarly, a study conducted in the Basque Country criticises the priority assigned to public use over the rural activities (forestry, livestock) of the PA (Etxano, 2009). Other researchers have shown that the offer of PA facilities for public use benefits the urban population much more than the rural population, which explains why the latter are unwilling to pay the resulting costs (Rodríguez, 2009). In this respect, Zubelzu and Hernández (2015) focus on willingness to pay to observe the landscape, obtaining similar results regarding low rates of acceptance. Rodríguez (2009) identifies a fundamental factor in this regard: in Spain, people are used to enjoying PAs at no direct cost, and this undoubtedly compromises the short and medium-term effectiveness of environmental protection mechanisms as a means of revitalising rural areas. On the other hand, PAs produce high levels of acceptance among the urban population (Martínez \& Romero, 2003). Regarding the lack of synergy, these authors emphasise the need for both PA management and tourism to be included in programmes that address "all types of resources (agriculture, livestock, forests, hunting, ...)" (Martínez \& Romero, 2003, p. 42). This conclusion is also reached by Serrano \& Aparicio (2017) and by Troitiño (1995). According to Regourd (2006), who conducted a study in this respect in the Southern Alps, this kind of coordination is also essential as a mechanism for revitalising rural economies, but it should be delivered via networks of local actors, at various levels, to overcome the individualism that Calvo (2011) detects as one of the factors that reduce the success of such programmes in Spain.

e.-The weakness of this area as a destination for tourism is acknowledged by the stakeholders themselves, who recognise the limitations faced by local entrepreneurs in detecting the resources highlighted by researchers as most significant for the economic diversification of rural areas, an awareness that is a necessary condition for diversifying the offer of outdoor recreational facilities by the private sector. In contrast, the initiatives taken within the LEADER programme have often focused directly on satisfying a hypothetical demand for rural tourism facilities without taking into account the attitude of local agents, who remain unaware of the existence of this supposed demand.

Numerous studies share this conclusion. Thus, Calvo (2011), Alberdi (2016), Cañete et al. (2017) and Moyano et al. (2017) all agree that the LEADER programmes have scant capacity to activate the rural productive fabric, and highlight the limited response of agents to initiatives taken in this regard. With respect to tourist activity, Van Straaten highlights the local population's lack of experience in this field as a factor that limits the ability of rural society to benefit from it, a factor also acknowledged by Cigale et al. (2013), who studied the situation in Slovenia, and 
by Mulero (2005), in a similar investigation in Spain, both of whom observed that mechanisms for local participation were insufficient.

2.- Future lines of research. Following this broad analysis of the policies and initiatives applied, any proposal of mechanisms that might enable the above limitations to be overcome must address a question of principle: how should different lines of action be prioritised? Our research shows that preferential investment in individual projects in this PA has not generated a cohesive, powerful productive fabric based on tourism. However, if further investment had been made to enhance entrepreneurial skills and strengthen organisational capital, what financing would subsequently have been available for private initiatives focused on materialising the entrepreneurial ambitions aroused by such an approach, based more on sociological than on economic grounds? Our response to the above questions is that the approach taken towards the revitalisation of PAs should be modified, starting not from the conceptual framework of the conversion of rural areas in general and of PAs in particular into tourist destinations, but rather to address the multifunctionality of agricultural land. Appropriate instruments in this respect would include the acquisition of skills training by property owners, programmes to raise awareness of the economic potential of providing services related to the ecosystem, the availability of funding for this purpose, and the provision of appropriate compensation for the inhabitants of the PA and its surroundings, for the ecosystem services facilitated. According to our bibliographic review, however, research findings in this regard remain inconclusive. Thus, a Europe-wide investigation conducted by Potocnik and Smith (2013) highlights the diversity of situations observed, giving rise to widely varying outcomes in the impact of agrotourism as an income-producing activity. This is corroborated by Marsat et al. (2013), in a study of the French region of Auvergne. On the contrary, Martínez and Romero (2003), who examine the special protection areas established for Danish fjords, and Talbot (2013), who analyses the situation of farms in Wales, report that these schemes do raise the income of local inhabitants, due to the compatibility of ecosystem services in the first case, and of agrarian services in the second. The other approach highlighted in our bibliographic review is the trend reported by Emerton et al. (2006, p. 33) for PA funding to be used as an instrument for conservation management. In this respect, they observe, "PA management costs are increasingly shared with users and other beneficiaries, while the responsibility for managing PAs is being devolved to communities and the private sector, helping both to reduce public sector costs and raising funds for PAs". This view, which we fully share, would represent a fundamental change in Spanish environmental policy, which until now has been much more inclined to benefit urban users than rural communities, whose interests have been relegated or ignored.

\section{Acknowledgement}

This paper is an outcome of the project Methodological Development on Assessing the Capacity of Protected Areas for Recreational Uses (Desarrollo metodológico sobre la evaluación de la capacidad para usos recreativos de espacios protegidos), reference SEJ2007, as part of the 2004-2007 National Plan for Scientific Research, Development and Technological Innovation, and the 2007 research excellence programme supported by the Department of Innovation, Science and Enterprise, reference 67690/GEOG.

\section{Academic references}

[1] Alberdi, J. C. (2016). Límites de la promoción rural en el País Vasco tras dos décadas de programas de desarrollo rural. Investigaciones Geográficas, 66, 59-78. DOI: 10.14198/INGEO2016.66.04.

[2] Antón, S., Blay, J. \& Salvat, J. (2008). Turismo, actividades recreativas y uso público en los parques naturales. Propuesta para la conservación de los valores ambientales y el desarrollo productivo local. Boletín de la Asociación de Geografía Española 48, 5-35. https://bage.agegeografia.es/ojs/index.php/bage/article/view/712. 
[3] Bachiller, J. M. (2012). Conflictos de intereses en la ordenación de un territorio de montaña: el turismo rural en la Tierra Pinariega soriana. Cuadernos de Turismo 29, 35-60. https://revistas.um.es/turismo/article/view/153191/134991.

[4] Ballesteros, G. (2014). El turismo de naturaleza en espacios naturales. El caso del parque regional de las salinas y arenales de San Pedro del Pinatar. Cuadernos de Turismo, 34, 3351. https://revistas.um.es/turismo/article/view/203011.

[5] Baños, C. \& Rico, E. (2016). La complementariedad litoral-interior en el marco de la renovación de destinos turísticos consolidados: el excursionismo organizado, como elemento de relación. Cuadernos de Turismo 38, 83-110. DOI: 10.6018/turismo.38.271361.

[6] Benito, E., Brida, J. G., Camino, A., Riaño, E., Such, M. J. (2011). Análisis de demanda de turismo rural en los pueblos de la arquitectura negra de Guadalajara. Cuadernos de Turismo 27, 57-75. https://revistas.um.es/turismo/article/view/139741.

[7] Benos, R., Cazenave, A. \& Milian, J. (2007). Pirineos-Monte Perdido Patrimonio mundial: un espacio de montaña frente a su protección y gestión. In Molinero, F., ed, III Coloquio HispanoFrancés de Geografía Rural / IlleColloque Franco-Espagnol de GéographieRurale (pp. 4763). Jaén: Ed. CD-Rom AGE, UNIA sede Antonio Machado, CNFG.

[8] Bericat, E. (1989). Cultura productiva y desarrollo endógeno. El caso andaluz. Revista de Estudios Regionales 24, 15-44.

[9] Calvo, R. (2011). Una mirada crítica al modelo de desarrollo económico en el ámbito local valenciano. Estrategias para su posible redefinición. Investigaciones geográficas 20,141152. https://investigacionesregionales.org/article/una-mirada-critica-al-modelo-dedesarrollo-economico-en-el-ambito-local-valenciano-estrategias-para-su-posibleredefinicion/.

[10] Cañete, J. A., Cejudo, E. \& Navarro, F. (2017). ¿Desarrollo rural o desarrollo de territorios rurales dinámicos? La contribución a los desequilibrios territoriales por parte de los Programas de Desarrollo en el sur de España, Andalucía. Anales de Geografía de la Universidad Complutense 37(2), 265-295. DOI: https://doi.org/10.5209/AGUC.57726.

[11] Capdepón, M. (2015). El papel de los parques naturales en los procesos de diversificación turística: una aplicación al litoral alicantino. Cuadernos de Turismo 35, 43-69. DOI: 10.6018/turismo.35.221501.

[12] Cigale, D., Lampič, B. \& Potočnik-Slavič, I. (2013). Interrelations between tourism offerand tourism demand in the case of farm tourism in Slovenia. European Countryside 5(4), 339355. https://doi.org/10.2478/euco-2013-0022.

[13] Ciervo, M. (2013). Agritourism in Italy and the local impact referring to Itria valley. The organic firm "Raggioverde" and its ecological agritourism project. European Countryside 5(4), 322338. DOI: 10.2478/euco-2013-0021.

[14] Clemens, C., Palacio, C. \& Lindenmeier, D. (2018). Outdoor recreation defined. Journal of the Oklahoma Association for Health, Physical Education, Recreation, and Dance 55(3), 5769. https://pdfs.semanticscholar.org/a5f5/68befd26a114587c335601d9a40b3196a5db.pdf.

[15] Cortijo, E. \& Pulido, M. (2016). Percepción de la población residente en Cañamero. Acerca del geoparque Villuercas-Ibores-Jara (Extremadura, España). Cuadernos de Turismo 37, 31-12. DOI: 10.6018/turismo.37.256161.

[16] Dudley, N. (Ed.) (2008). Guidelines for applying protected area management categories. Gland, Switzerland. http://data.iucn.org/dbtw-wpd/edocs/paps-016.pdf.

[17] Emerton, L., Bishop, J. \& Thomas, L. (2006). Sustainable financing of protected areas. A global review of challenges and options. Gland: IUCN.

[18] Esparcia, J. \& Buciega, A. (2005). New rural-urban relationships in Europe: A comparative Analysis. Experiences from The Netherlands, Spain, Hungary, Finland and France. Valencia: Universitat de Valéncia e Instituto Interuniversitario de Desarrollo Local. 
[19] Etxano, I. (2009). Desarrollo rural en espacios naturales protegidos: el caso del parque natural de Gorbeia (1994-2008). Lurr@alde 32, 197-226. http://hdl.handle.net/10810/12138.

[20] Fernández, A. \& Santos, E. (2010). Turismo y Parques Naturales en Andalucía tras veinte años desde su declaración. Análisis estadístico, tipología de parques y problemática de la situación actual. Anales de Geografía de la Universidad Complutense 30(1), 29-54. DOI: 0211-9803.

[21] García, R. (2011). Turismo y desarrollo rural en la comarca del noroeste de la región de Murcia: los programas europeos LEADER. Cuadernos de Turismo 27, 419-435. https://revistas.um.es/turismo/article/view/140031.

[22] García, T. \& Barrena, R. (2013). Preferencias del visitante de establecimientos de turismo rural. Estudio en Navarra. Cuadernos de Turismo 32, 141-153. https://revistas.um.es/turismo/article/view/177491.

[23] Gerbaux, F. \& Bozonnet, J. P., eds. (1979). La montagne, espace delaisse, espace convoite. Grenoble: Presses Universitaires de Grenoble.

[24] Horáková, H. (2013). Whose countryside? Contested development in the new rural recreational localities in Czechia from the perspective of the countryside capital. European Countryside 5(1), 21-37. DOI: 10.2478/euco-2013-0002.

[25] Jiménez, M., Ruiz, J. \& Peña, A. R. (2015). Análisis de las zonas rurales andaluzas y su turismo, desde una óptica de proximidad geográfica a los núcleos urbanos andaluces. Investigaciones Regionales 31, 59-74. DOI: http://dx.doi.org/10.14198/INTURI2019.18.04.

[26] Leco, F., Mateos, A. B. \& Pérez, A. (2015). Estudio de la demanda del turismo en el parque nacional y reserva de la biosfera de Monfragüe. Cuadernos de Turismo 35, 231-257. DOI: 10.6018/turismo.35.221591.

[27] López, A., Pons, A. \& Noguera, M. (2007). Utilización de las categorías de gestión de áreas protegidas de UICN en la región mediterránea. Sevilla: Junta de Andalucía \& UICN. https://portals.iucn.org/library/sites/library/files/documents/2007-016.pdf.

[28] Luque-Gil, A., Gómez-Moreno, M. L. \& Peláez-Fernández, M. A. (2018). Starting to enjoy nature in Mediterranean mountains: Crowding perception and satisfaction. Tourism Management Perspectives 25, 93-103. DOI: 10.1016/j.tmp.2017.11.006.

[29] Marsat, J. B., Menegazzi, P., Monin, C., Bonniot, A. \& Bouchaud, M. (2013). Designing a regional policy of agrotourism. The case of Auvergne region (France). European Countryside 5(4), 308-321. DOI: 10.2478/euco-2013-0020.

[30] Martínez, J. \& Romero, R. (2003). Repercusión de los espacios naturales protegidos en la economía rural española. Serie geográfica 11, 41-60. https://www.researchgate.net/publication/237516194_REPERCUSION_DE_LOS_ESPACI OS_NATURALES_PROTEGIDOS_EN_LA_ECONOMIA_RURAL_ESPANOLA.

[31] Mayer, M. \& Job, H. (2014). The economics of protected areas, a European perspective. Zeitschrift für Wirtschaftsgeographie. 58(1), 73-97. DOI: 10.1515/zfw.2014.0006.

[32] Moyano, P., Miranda, B. \& Gordo, P. (2017). La participación de los agentes económicos y sociales en la revitalización de los municipios rurales. Investigaciones regionales 38, 91115. https://investigacionesregionales.org/article/la-participacion-de-los-agenteseconomicos-y-sociales-en-la-revitalizacion-de-los-municipios-rurales/.

[33] Mulero, A. (2005). Espacios naturales protegidos y desarrollo rural en España: Ios Planes de Desarrollo Sostenible. Eria 68, 315-330. http://hdl.handle.net/10396/3680.

[34] Ocaña, C., Gómez, M. L., Arrebola, J. A., Blanco, R., Galacho, F. B., Larrubia, R., Luque, A., Mérida, M., Navarro, S., Rubio, L. M. \& Vías, J. (2012). Desarrollo metodológico sobre la evaluación de la capacidad de uso recreativo de espacios protegidos. Nimbus 29-30, 447-460. https://dialnet.unirioja.es/servlet/articulo?codigo=4376866. 
[35] Pecqueur, B. (2001). Qualité et development territorial: l'hypothese du panier de biens et de services territorialises. Economie Rurale 261(1), 37-49. https://www.persee.fr/doc/ecoru_0013-0559_2001_num_261_1_5217.

[36] Pillet, F. (2011). El turismo de interior y el patrimonio territorial en Castilla-La Mancha. Cuadernos de Turismo 27, 725-741. https://revistas.um.es/turismo/article/view/140181.

[37] Potocnik-Slavic, I. \& Schmitz, S. (2013). Farm tourism across Europe. European countryside 5(4), 265-274. DOl: https://doi.org/10.2478/euco-2013-0017.

[38] Prados, M. J., ed. (2008). Naturbanization: New identities and processes for rural-natural areas. Leiden: CRC Press.

[39] Prost, B. (1994). L'agriculture periurbaine: analyse d'une marginalité. Bulletin de la Association de géographes français 71(2), 144-151. https://www.persee.fr/doc/bagf_00045322_1994_num_71_2_1728.

[40] Pulido, J. I. (2008). Gestión turística y desarrollo económico en los parques naturales andaluces. Una propuesta de revisión desde el análisis del posicionamiento de sus actuales gestores. Revista de Estudios Regionales 81, 171-203. http://www.revistaestudiosregionales.com/documentos/articulos/pdf1034.pdf.

[41] Regourd, E. (2006). Nouvelles dynamiques du développement rural dans les Alpes du Sud. Méditerranée 107, 13-22. https://doi.org/10.4000/mediterranee.206.

[42] Reinoso, D. \& Sancho, R. (2011). El nuevo parque natural de la Sierra Norte de Guadalajara: un espacio turístico-recreativo con importantes valores patrimoniales. Cuadernos de Turismo 27, 811-822. https://revistas.um.es/turismo/article/view/140231.

[43] Rizzo, F. (2013). LEADER policy practices and landscapes in the light of the agencystructure debate: evidence from LEADER local action groups in Italy and in Finland. European Countryside 5(3), 232-250. DOI: 10.2478/euco-2013-0015.

[44] Rodríguez, D. (2009). Mitigación de los impactos del turismo en espacios naturales protegidos y mejora de su financiación a través de medidas económicas. El caso de la Comunidad de Madrid. Boletín de la Asociación de Geógrafos Españoles, 50, 217-239. https://bage.agegeografia.es/ojs/index.php/bage/article/view/1106/1029.

[45] Sánchez, J. M., Sánchez, M. \& Rengifo, J. I. (2017). Análisis del equilibrio entre el potencial turístico y la oferta de alojamientos en turismo rural mediante técnicas de estadística espacial. Una aplicación a la provincia de Cáceres (España). Cuadernos de Turismo 39, 547-576. DOI: 10.6018/turismo.39.290701.

[46] Senciales, J. M., Delgado, J. J., Gómez, M. L. \& López, J. (2017). Itinerario por la Sierra de las Nieves y el Desfiladero de los Gaitanes. In Ruiz, J. D., Galacho, F. B. \& Martínez, J. F., eds., Itinerarios geográficos por la provincia de Málaga (pp. 110-126). Málaga: Servicio de Publicaciones de la Universidad de Málaga.

[47] Serrano, O. (2008). Efectos de la declaración de un espacio natural protegido en territorios de ruralidad profunda. Scripta Nova 12(270). http://www.ub.es/geocrit/sn/sn-270/sn-27085.htm.

[48] Serrano, O. \& Aparicio. E. (2017). La oferta turística vinculada a las áreas de influencia socioeconómica de los parques nacionales de Castilla-La Mancha: Tablas de Daimiel y Cabañeros. Cuadernos de Turismo, 39, 577-600. DOI: 10.6018/turismo.39.290711.

[49] Simón, A. \& Zazo, A. \& Morán, N. \& Hernández, V. (2014). Pathways towards the integration of periurban agrarian ecosystems into the spatial planning system. Ecological Processes, 3 , 13. DOI: 10.1186/s13717-014-0013-x.

[50] Spotorno, M. (2005). Le Parc nature régional de Portofino en Ligurie. Méditerranée 105(34), 47-52. https://doi.org/10.4000/mediterranee.342. 
[51] Talbot, M. (2013). Farm tourism in Wales. Products and markets, resources and capabilities. The experience of six farm tourism operators. European Countryside 5(4), 275-294. DOI: 10.2478/euco-2013-0018.

[52] Tolón, A. \& García, A. (2002). La planificación turística en espacios naturales protegidos. Estudios geográficos 63(247), 303-320. https://doi.org/10.3989/egeogr.2002.i247.254.

[53] Troitiño, M. A. (1995). Espacios naturales protegidos y desarrollo rural: Una relación territorial conflictiva. Boletín de la Asociación de Geografía Española 20, 23-37. https://dialnet.unirioja.es/servlet/articulo?codigo=1318470.

[54] Van der Straaten, J. (2000). Can sustainable tourism positively influence rural regions? In Hall, D. \& Roberts, G., eds., Tourism and Sustainable Community development (pp. 221233). New York: Routledge.

[55] Wagar, J. A. (1964). The carrying capacity of wildlands for recreation. Forest Science Monograph 10(Suppl. 2), 1-24. DOI: 10.1093/forestscience/10.s2.a0001.

[56] Zubelzu, S. \& Hernández, A. (2015). Deporte, cultura, turismo y medioambiente. Disponibilidad a pagar por los paisajes agrarios como activo turístico. International Journal of Scientific Management and Tourism, 1, 73-93. https://dialnet.unirioja.es/servlet/articulo?codigo $=5665857$.

Other sources

[57] AGDR 2000-2006 (Asociación Grupo de Desarrollo Rural Sierra de las Nieves). Estrategia de Desarrollo del AGDR Sierra de las Nieves para la ejecución del programa de Desarrollo Rural Leader +. Impresión en papel, consultadas en AGDR Sierra de las Nieves, C/ Pozo $n^{\circ} 17$, Yunquera, Málaga, Spain.

[58] EUROPARC-ESPAÑA. Anuario 2013 del estado de las áreas protegidas en España. Available from: http://www.redeuroparc.org/anuario_europarc_espana.jsp.

[59] European Environmental Agency Report No. 5-2012. Protected areas in Europe, an overview. Luxembourg.

[60] Junta de Andalucía (2003). Decreto 344/2003, de 9 de diciembre, por el que se aprueba el PORN y PRUG del Parque Natural Sierra de las Nieves [2003 Natural resourcesmanagementplansforthe Sierra de las Nieves natural park] (Boja $\mathrm{n}^{\circ}$ 14, de 22 de enero de 2004). Available at

http://www.juntadeandalucia.es/medioambiente/portal_web/web/temas_ambientales/espaci os_protegidos/planificacion/PORN/PORN_PRUG_Sierra_Nieves/decreto344snieves.pdf Lastaccessed: November 2012.

[61] LEADER European Observatory (2001). Developing walking holidays in rural areas: Guide on how to design and implement a walking holiday project. Available from: http://ec.europa.eu/agriculture/rur/leader2/rural-en/biblio/walking/walking.pdf.

[62] PRAMES, Area de consultoría, medio ambiente y formación (2003). Estudio de aproximación ambiental y socioeconómica a la influencia de las actividades de senderismo y excursionismo en la provincia de Huesca. INFORME. 